\title{
EFFECT OF SOME PLANT GROWTH REGULATORS AND BIOSTIMULANTS ON THE PRODUCTIVITY OF SAKHA108 RICE PLANT (ORYZA SATIVA L.) UNDER DIFFERENT WATER STRESS CONDITIONS
}

\author{
AbDel Megeed, T. M. ${ }^{1 *}-$ GHARIB, H. S. ${ }^{2}-$ HAFEZ, E. M. ${ }^{2}-$ El-SAYed, A. ${ }^{2}$ \\ ${ }^{1}$ Rice Research and Training Center, Field Crops Research Institute, Agricultural Research \\ Center, Kafrelsheikh, Egypt \\ ${ }^{2}$ Agronomy Department, Faculty Agriculture Kafrelsheikh University, Kafrelsheikh, Egypt \\ *Corresponding author \\ e-mail:dr_tmk2002@yahoo.com; phone: +20-100-40-55681; fax: +20-473-223-683
}

(Received $16^{\text {th }}$ Sep 2020; accepted $30^{\text {th }}$ Nov 2020)

\begin{abstract}
In order to study the effect of biostimulants and growth regulator foliar application (PGRs) under different level of water stress, a field experiment was conducted to find out the role of some plant biostimulants and plant growth regulating substances on a rice cultivar grown under different irrigation intervals in the 2018 and 2019 growing seasons at the farm of Agricultural Research Station, Sakha, Kafrelsheikh, Egypt. The Experiment was conducted using Randomized Complete Block Design with Strip plot arrangements. Main plots consisted of the four irrigation intervals while sub plots contained the different plant biostimulants and plant growth regulators with different concentrations. Some growth characteristics, yield components were recorded. The main results indicated that spraying plant substances during this study increased all studied characters as compared to control treatment. Spraying with Crop plus surpassed and gave the highest value in all the studied characters followed by Cytokinin. Spraying Crop plus under irrigation every 12 days which cause water stress, relieve the harm of stress in the plant and increase the yield by about $2.47 \mathrm{t} / \mathrm{ha}$ as compared with control. These results are beneficial for farmers who suffer from shortage of irrigation water in their rice field.
\end{abstract}

Keywords: crop plus, cytokinin (CK), abscisic acid (ABA), leaf area index, chlorophyll content, yield

\section{Introduction}

Rice is a major summer crop in Egypt, occupying 10 percent of total crop area. Rice requires a special irrigation regime and its cultivation is largely restricted to the northern part of the Delta. It is often planted on low quality land where the soil is fairly saline and has varying degrees of productivity. Farmers normally exceed the area targeted by the government for rice cultivation despite the prospect of fines (LE 1434/hectare) for those who violate their targeted areas. This is due to the much higher profitability of rice cultivation compared to other traditional summer crops (i.e. corn and cotton) and the higher potent for exporting the crop. The government is trying to restrict the area of rice and increase the area of corn to save water.

Rice is particularly susceptible to soil water deficit, which causes large yield losses in many Asian countries. And drought affects its growth in about 50\% of the world production area. More than $50 \%$ of the 40 million ha of rain fed lowland rice area in South and Southeast Asia is affected by drought annually, which has contributed to significant yield losses.

Generally, reduction of water content in plant tissues under drought conditions limits their growth. Studies show that the stress caused by water shortage reduces growth and leaf surface area, damages and reduces photosynthetic processes, damages cell 
membranes, damages and reduces proteins and enzymes, hurts pigments and plastids, and reduces chlorophyll and root growth (Levitt, 1980). Water shortage stress can directly affect photosynthesis related biochemical processes while it indirectly reduces $\mathrm{CO}_{2}$ molecules entering stomata which are closed due to water shortage. As a result, transportation of photosynthetic substances are affected by water shortage and leaves become saturated which in turn may further limit photosynthesis. Limitation in photosynthetic substances under water shortage will obviously reduce plant growth and eventually its photosynthesis and performance (Blum, 1996).

The plant bio-stimulants, include diverse substances and microorganisms that enhance plant growth. The global markets for bio-stimulants has been projected to reach $\$ 2.241$ million by 2018 and to have a compound annual growth rate of $12.5 \%$ from 2013 to 2018 (Anonymous, 2013). The European bio-stimulants industry council (EBIC) reported that in 2012 over 6.2 million hectares were treated with bio-stimulants (European Bio-stimulants Industry Council, 2013). Also, contains macro elements' (e.g.: $\mathrm{Ca}, \mathrm{K}$ and P) and microelements (Fe, Cu, Zn, B, Mn, Co and Mo) (Craigie, 2011). Seaweed extracts a positive impact of several species of algae (Ascophyllum sp., Laminaria sp. and Ecklonia sp) on growth and development (Sultana et al., 2005). Seaweed extracts are now available commercially under the names, such as Maxi crop (Seaborn), Algifert (Marinure), Goemar GA14, Kelpak66, Crop plus, Seaspray, Seasol, and Seacrop16. Recently researchers proved that seaweed fertilizer are better than other fertilizers and are very economical (Ramya et al., 2011).

Biozyme Crop plus is a commercial formulation of seaweed extract (Ascophyllum nodosum), enzymes and hydrolyzed proteins whereas, spic cytozyme contain gibberellic acid, auxins, cytokinins, seaweed extract (Ascophyllum nodoum), hydrolysed proteins and trace elements.

Cytokinins (CKs) promote cell division and, acting both in synergy and antagonism with other plant hormones, influence a wide range of events during plant growth. The major portion of CKs is produced in meristematic regions in the root system and transported via the xylem to the shoot. These CKs, along with the locally synthesized CKs, control the development and senescence of the whole plant. CKs promote leaf expansion, accumulation of chlorophyll and conversion of etioplasts into chloroplasts, and delay leaf senescence. The molecular mechanism of CK action is only poorly understood and information on how endogenous CKs are affected under stress is meager (Pospíšilová et al., 2000). Plant responses to CKs are often judged from their responses to exogenously applied CKs. However, when CKs are applied and plant response have been followed, it is necessary to take into consideration that exogenous CKs (natural and synthetic) can increase the content of endogenous CKs by their uptake and by promotion of CK biosynthesis. On the other hand, they can increase cytokinin oxidase activity and CK degradation (Hare et al., 1997; Kamínek et al., 1997). Thus, the composition and concentration of CKs in the site of action might be quite different than in the site of application.

The plant hormone abscisic acid (ABA) plays a major role in plant responses to stress. Although rapid production of $\mathrm{ABA}$ in response to drought and salt stresses is essential to define ABA as a stress hormone, an equally rapid catabolism of ABA when such stresses are relieved is also essential in that role. Among these regulated physiological responses, the plant hormone abscisic acid (ABA) plays a central role. $\mathrm{ABA}$ is defined as a stress hormone because of its rapid accumulation in response to stresses and its mediation of many stress responses that help plant survival over the 
stresses. How can this substance achieve this purpose? The first prerequisite is that its production should be sensitively and rapidly triggered by the stress to avoid any inhibition of plant growth and functions under unstressed conditions. The second prerequisite is that ABA should be rapidly degraded and deactivated once the stress is relieved such that normal plant growth and functions can resume (Zhang et al., 2006).

Application of CKs can reverse leaf and fruit abscission induced by ABA or water stress, or CKs release seed dormancy in contrasts with ABA inhibition of germination. The antagonism between CKs and ABA may be the result of metabolic interactions. CKs share, at least in part, a common biosynthetic origin with ABA (Cowan et al., 1999).

Various studies show that water stress negatively affects plants including rice and reduce yields in crops. Application of hormones and growth regulators on the other hand, improves growth parameters in the plants under drought stress. Therefore, the present study aimed to investigate the effect of foliar different plant growth regulator and biostimulants on Sakha108 rice variety production under different levels of drought stress under Egyptian conditions.

\section{Materials and methods}

A field experiment was carried out in the farm of Agricultural Research Station, Sakha, Kafrelsheikh, Egypt, the latitude and longitude of the field experiment $\left(31^{\circ} 05^{\prime} 17^{\prime \prime} \mathrm{N}, 30^{\circ} 56^{\prime} 44^{\prime \prime} \mathrm{E}\right)$ and the experimental conditions of the study have been described in Table 1 during 2018 and 2019 in rice growing seasons to identify the impact of foliar application of bio-stimulants by different levels of seaweed extracts named commercially [Crop plus at rates $0.5,1.00$ and $1.5 \mathrm{ml} / 1$ liter water]. Biozyme Crop plus is a commercial formulation of seaweed extract (Ascophyllum nodosum), enzymes and hydrolyzed proteins whereas, spic cytozyme contain gibberellic acid, auxins, cytokinins, seaweed extract (Ascophyllum nodoum), hydrolysed proteins and trace elements and plant growth regulator named i.e. [Cytokinin (CK) and Abscisic acid with concentration of 15, 20, $25 \mathrm{ppm}$ ) and Trafos $\mathrm{K}$ (Trafos $\mathrm{K}$ is a registered trademark of products Trade crop nutri-performance, Co., in Spain, it has been obtained from Perfect-Egypt Company, Al-Sadat City. The chemical composition of Trafos $\mathrm{K}$ is Phosphorus " $\mathrm{P}_{2} \mathrm{O}_{5}$ " 42\% (w/v) and Potassium " $\mathrm{K}_{2} \mathrm{O}$ " $28 \%(\mathrm{w} / \mathrm{v})$, in the form potassium phosphite at rates $1,1.5$ and $2 \mathrm{ml} / \mathrm{l}$ liter water) to improve the vegetative and reproductive growth of Sakha108 rice cultivar under different irrigation intervals i.e. irrigation every 3 days $\left(\mathrm{I}_{1}\right)$, irrigation every 6 days $\left(\mathrm{I}_{2}\right)$, irrigation every 9 days $\left(\mathrm{I}_{3}\right)$ and irrigation every 12 days $\left(\mathrm{I}_{4}\right)$ (water stress). The field experiments were laid out in a strip design with four replications. The irrigation treatments were applied in the main plots, while the plant growth biostimulating growth regulating substances (PGRs) and Trafos $\mathrm{K}$ as shown in Table 2 were placed in the sub- plots. Rice variety was sprayed with plant bio-stimulated, growth regulators (PGRs) and Trafos-K four time after 15, 30, 45 and $60 \mathrm{DAT}$. Pre-germinated seeds of rice cultivar at the rate of $120 \mathrm{Kg} / \mathrm{ha}$, were broadcasted manually in the nursery on 10th of May in 2018 and 2019 seasons. Nitrogen (Urea 46\% N) was added according to the treatments in two splits. Two thirds added as basal and incorporated in dry soil before flooding. The other $1 / 3$ was applied as top-dress just before panicle initiation (about 30 days after transplanting). Phosphorus as a single super phosphate $15 \%$ at the rate of $36.89 \mathrm{~kg} \mathrm{P}_{2} \mathrm{O}_{5} /$ ha was added to the soil before tillage and zinc $\left(\mathrm{ZnSO}_{4}\right)$ was applied as recommended at the rate of $24 \mathrm{~kg} \mathrm{ZnSO} / \mathrm{ha}$. 
Table 1. Means of climate parameters of the experimental site during 2018 and 2019 seasons

\begin{tabular}{c|c|c|c|c|c}
\hline Years & Climatic condition & May & June & July & August \\
\hline \multirow{2}{*}{2018} & Air temp $\left({ }^{\circ} \mathrm{C}\right)$ & 27.5 & 28.95 & 29.8 & 29.55 \\
& $\mathrm{RH}(\%)$ & 59.75 & 61.75 & 66.8 & 66.9 \\
\hline \multirow{2}{*}{2019} & Air temp $\left({ }^{\circ} \mathrm{C}\right)$ & 28.65 & 30.5 & 30.95 & 31.55 \\
& $\mathrm{RH}(\%)$ & 57.15 & 65.75 & 69.8 & 72.65 \\
\hline
\end{tabular}

Table 2. Plant bio stimulants and the amount of this component during period of rice plant growing

\begin{tabular}{c|c|c|c|c|c}
\hline No & Growth biostimulants & Dose & No & $\begin{array}{c}\text { Growth } \\
\text { biostimulants }\end{array}$ & Dose \\
\hline 1 & Crop Plus $\left(\mathrm{T}_{1}\right)$ & $0.5 \mathrm{ml} / 1$ liter water & 8 & $\mathrm{ABA}\left(\mathrm{T}_{8}\right)$ & $20 \mathrm{ppm}$ \\
2 & Crop Plus $\left(\mathrm{T}_{2}\right)$ & $1.0 \mathrm{ml} / 1$ liter water & 9 & ABA $\left(\mathrm{T}_{9}\right)$ & $25 \mathrm{ppm}$ \\
3 & Crop Plus $\left(\mathrm{T}_{3}\right)$ & $1.5 \mathrm{ml} / 1$ liter water & 10 & Trafos $\mathrm{K}\left(\mathrm{T}_{10}\right)$ & $1 \mathrm{ml} / 1$ liter water \\
4 & Cytokinin $\left(\mathrm{T}_{4}\right)$ & $15 \mathrm{ppm}$ & 11 & Trafos $\mathrm{K}\left(\mathrm{T}_{11}\right)$ & $1.5 \mathrm{ml} / 1$ liter water \\
5 & Cytokinin $\left(\mathrm{T}_{5}\right)$ & $20 \mathrm{ppm}$ & 12 & Trafos $\mathrm{K}\left(\mathrm{T}_{12}\right)$ & $2 \mathrm{ml} / 1$ liter water \\
6 & Cytokinin $\left(\mathrm{T}_{6}\right)$ & $25 \mathrm{ppm}$ & 13 & Tap water $\left(\mathrm{T}_{13}\right)$ & - \\
7 & ABA $\left(\mathrm{T}_{7}\right)$ & $15 \mathrm{ppm}$ & & & - \\
\hline
\end{tabular}

Seedlings were manually pulled and transferred to the permanent field and transplanted in $20 \times 20 \mathrm{~cm}$ between rows and hills. The sub plot size was $12 \mathrm{~m}^{2}$. The number of seedling/hill was 2-3 seedlings. Seven days after transplanting, the herbicide Saturn 50\% [S-(4-Chlorophenol methyl) diethyl carbamothioate] at the rate of $4.8 \mathrm{~L} \mathrm{ha}^{-1}$ was mixed with enough amount of sand to make it easy for homogenous distribution to control the weeds. Leaf area index, chlorophyll content of flag leaf using (SPAD) chlorophyll meter Minolta camera Co. Ltd., Japan, dry matter, number of tillers $/ \mathrm{m}^{2}$, number of panicles $/ \mathrm{m}^{2}$, number of filled grains/panicle, panicle weight (g), 1000-grain weight $(\mathrm{g})$ and grain yield $(\mathrm{t} / \mathrm{ha})$ were estimated.

Representative soil samples were taken from the experimental sites at $(0-30 \mathrm{~cm})$ depth from soil surface. Chemical analyses were done and the results are presented in Table 3 according to Black et al. (1965).

Table 3. Soil mechanical and chemical properties of the experimental site

\begin{tabular}{c|c|c|c|c|c|c|c}
\hline $\begin{array}{c}\text { Seasons of } \\
\text { study }\end{array}$ & $\begin{array}{c}\text { Soil texture } \\
(\mathbf{\%})\end{array}$ & $\mathbf{p H}$ & $\begin{array}{c}\mathbf{E C} \\
\mathbf{d S} / \mathbf{m}\end{array}$ & $\begin{array}{c}\text { Organic } \\
\text { matter } \mathbf{( \% )})\end{array}$ & $\begin{array}{c}\text { Available N } \\
\left(\mathbf{m g ~ k g}^{-1}\right)\end{array}$ & $\begin{array}{c}\text { Available P } \\
\left(\mathbf{m g ~ k g}^{-1}\right)\end{array}$ & $\begin{array}{c}\text { Available K } \\
\left(\mathbf{m g ~ k g}^{-1}\right)\end{array}$ \\
\hline 2018 & Clayed & 7.9 & 1.8 & 1.65 & 22.5 & 14.45 & 346 \\
2019 & Clayed & 8.1 & 1.45 & 1.68 & 24.4 & 14.12 & 357 \\
\hline
\end{tabular}

\section{Statistical analysis}

The collected data were subjected to statistical analysis and were tested at 5\% level of significance to interpret the differences among the treatments, which adapted by Waller and Duncan (1969). All the collected data were subjected to statistical analysis according to procedure described by Gomes and Gomes (1984). 


\section{Results and discussion}

\section{Leaf area index}

Data in Table 4 clearly assured that, irrigation of rice every 3 days recorded the highest leaf area index followed by irrigation every 6 and 9 days. While irrigation every 12 days significantly reduced the leaf area index. It might be due to the effect of the stress of water shortage caused by irrigation every 12 days which affected rice growth. These results are in harmony with that recorded by Abd Allah et al. (2009), AbdelMegeed et al. (2017) and Zheng et al. (2020).

From the results presented in Table 4 it can be easily noticed that spraying high concentration of Crop plus at the rate of $1.5 \mathrm{ml}$ gave the highest leaf area index followed by next concentration of the same regulator 1.00 and $0.5 \mathrm{ml}$ respectively. While the high concentration of Cytokinin $(25 \mathrm{ppm})$ come in the second rank after Crop plus and recorded positive result. Whereas, control gave the lowest value of leaf area index in both seasons. These results are in coincidence with that reported by Gemici et al. (1998, 2002), Houssien et al. (2011), Prajapati and Modi (2012) and Abdel-Megeed et al. (2017).

Table 4. Leaf area index (LAI), Chlorophyll content, dry matter production (DM) $\left(\mathrm{g} / \mathrm{m}^{2}\right)$ of Sakha108 rice cultivars as affected by different irrigation intervals and growth regulators during 2018 and 2019 season

\begin{tabular}{|c|c|c|c|c|c|c|}
\hline \multirow[b]{2}{*}{ Treatments } & \multicolumn{3}{|c|}{2018} & \multicolumn{3}{|c|}{2019} \\
\hline & LAI & $\begin{array}{c}\text { Chlorophyll } \\
\text { content }\end{array}$ & DM & LAI & $\begin{array}{c}\text { Chlorophyll } \\
\text { content }\end{array}$ & DM \\
\hline Irrigation interval (A) & & & & & & \\
\hline$\left(\mathrm{I}_{1}\right)$ & $4.20 \mathrm{a}$ & $43.86 a$ & $1574.4 \mathrm{a}$ & $4.526 \mathrm{a}$ & $43.124 \mathrm{a}$ & $1578.8 \mathrm{a}$ \\
\hline$\left(\mathrm{I}_{2}\right)$ & $3.91 \mathrm{ab}$ & $42.75 b$ & $1421.8 b$ & $4.196 b$ & $42.013 b$ & $1426.2 b$ \\
\hline$\left(\mathrm{I}_{3}\right)$ & $3.79 b$ & $41.47 \mathrm{c}$ & $1311.9 \mathrm{c}$ & $4.104 b$ & $40.732 \mathrm{c}$ & $1316.3 \mathrm{c}$ \\
\hline$\left(\mathrm{I}_{4}\right)$ & $3.27 \mathrm{c}$ & $40.94 d$ & $1202.0 \mathrm{~d}$ & $3.573 \mathrm{c}$ & $40.208 c$ & $1206.5 d$ \\
\hline F. Test & $* *$ & $* *$ & $* *$ & $* *$ & $* *$ & $* *$ \\
\hline$\frac{\text { Growth regulates }}{\text { treatment }(\mathrm{B})}$ & & & & & & \\
\hline$\left(\mathrm{T}_{1}\right)$ & $4.51 \mathrm{abc}$ & $44.36 \mathrm{bc}$ & $1553.4 \mathrm{a}$ & $4.82 b$ & $43.63 \mathrm{bc}$ & $1557.8 \mathrm{a}$ \\
\hline$\left(\mathrm{T}_{2}\right)$ & $4.67 \mathrm{ab}$ & $44.90 \mathrm{ab}$ & $1560.2 \mathrm{a}$ & 4.99ab & $44.17 \mathrm{ab}$ & $1564.6 \mathrm{a}$ \\
\hline$\left(\mathrm{T}_{3}\right)$ & $5.05 \mathrm{a}$ & $45.35 \mathrm{a}$ & $1573.1 \mathrm{a}$ & $5.14 \mathrm{a}$ & $44.62 \mathrm{a}$ & $1577.5 \mathrm{a}$ \\
\hline$\left(\mathrm{T}_{4}\right)$ & $3.85 \mathrm{cde}$ & $42.45 \mathrm{e}$ & $1408.8 \mathrm{~d}$ & $4.18 \mathrm{~d}$ & $41.71 \mathrm{e}$ & $1413.2 \mathrm{~d}$ \\
\hline$\left(\mathrm{T}_{5}\right)$ & $4.11 \mathrm{bcd}$ & $43.41 \mathrm{~d}$ & $1481.8 \mathrm{c}$ & $4.43 c$ & $42.68 \mathrm{~d}$ & $1486.2 \mathrm{c}$ \\
\hline$\left(\mathrm{T}_{6}\right)$ & $4.22 \mathrm{bcd}$ & $43.80 \mathrm{~cd}$ & $1510.7 b$ & $4.54 \mathrm{c}$ & $43.07 \mathrm{~cd}$ & $1515.2 b$ \\
\hline$\left(\mathrm{T}_{7}\right)$ & 3.30ef & $41.18 \mathrm{f}-\mathrm{h}$ & $1299.0 \mathrm{e}$ & $3.63 f$ & $40.45 f-h$ & $1303.5 \mathrm{e}$ \\
\hline$\left(\mathrm{T}_{8}\right)$ & $3.56 \mathrm{de}$ & $41.38 f g$ & $1394.1 d$ & $3.90 \mathrm{e}$ & $40.65 \mathrm{fg}$ & $1398.5 d$ \\
\hline$\left(\mathrm{T}_{9}\right)$ & 3.70de & $41.58 f$ & $1399.7 d$ & $4.03 \mathrm{de}$ & $40.84 f$ & $1404.2 d$ \\
\hline$\left(\mathrm{T}_{10}\right)$ & $3.14 \mathrm{ef}$ & $40.27 \mathrm{i}$ & $1165.4 \mathrm{gh}$ & $3.46 f$ & $39.53 \mathrm{i}$ & $1169.8 \mathrm{gh}$ \\
\hline$\left(\mathrm{T}_{11}\right)$ & $3.26 \mathrm{ef}$ & 40.54hi & $1172.5 \mathrm{~g}$ & $3.58 \mathrm{f}$ & 39.81hi & $1176.9 \mathrm{~g}$ \\
\hline$\left(\mathrm{T}_{12}\right)$ & $3.30 \mathrm{ef}$ & 40.65ghi & $1237.6 \mathrm{f}$ & $3.62 \mathrm{f}$ & 39.92ghi & $1242.1 \mathrm{f}$ \\
\hline$\left(\mathrm{T}_{13}\right)$ & $2.66 \mathrm{f}$ & $39.43 \mathrm{j}$ & $1151.6 \mathrm{~h}$ & $2.99 \mathrm{~g}$ & $38.69 \mathrm{j}$ & $1156.0 \mathrm{~h}$ \\
\hline F. Test & $* *$ & $* *$ & $*$ & $* *$ & $* *$ & $*$ \\
\hline Interaction: $\mathrm{AXB}$ & $* *$ & $*$ & $*$ & $* *$ & $*$ & $*$ \\
\hline
\end{tabular}

I1: irrigation every3-days, I2: irrigation every 6-days, I3: irrigation every 9-days, I4: irrigation every 12days, $\mathrm{T}_{1}: 0.5 \mathrm{ml}$ Crop plus, $\mathrm{T}_{2}: 1.00 \mathrm{ml}$ Crop plus, $\mathrm{T}_{3}: 1.5 \mathrm{ml}$ Crop plus, $\mathrm{T}_{4}: 15 \mathrm{ppm}$ Cytokinin, $\mathrm{T}_{5}: 20$ ppm Cytokinin, $\mathrm{T}_{6}: 25 \mathrm{ppm}$ Cytokinin, $\mathrm{T}_{7}: 15 \mathrm{ppm}$ ABA, $\mathrm{T}_{8}: 20 \mathrm{ppm}$ ABA, $\mathrm{T}_{9}: 25 \mathrm{ppm}$ ABA, $\mathrm{T}_{10}: 1 \mathrm{ml}$ Trafos K, $\mathrm{T}_{11}: 1.5 \mathrm{ml}$ Trafos K, $\mathrm{T}_{12}: 2 \mathrm{ml}$ Trafos K, $\mathrm{T}_{13}$ : Tap water 
The interaction between different water intervals and foliar spraying had a significant influence on leaf area index. From the results presented in Table 5, it could be concluded that rice plant which treated with any plant growth regulator (PGRs) recorded positive result of leaf area index as value. Where, rice plants treated with high concentration of Crop plus $1.5 \mathrm{ml}$ gave the highest plant height under different time of irrigation even 3, 6, 9 and 12-days and recorded the highest value of leaf area index. It means that tested rice cultivar sprayed by Crop plus led to extending the irrigation interval from 3-days up to every 12-days consequently saving reasonable amount of irrigation water without significant reduction in the sink capacity (leaf area index). While the lowest value of leaf area index was found with irrigation every 12 days under control treatment (without any spray). Such findings had also been pointed out by Bahattacharjee et al. (1973), De Datta et al. (1973) and Kang (1998).

Whereas, spraying with any plant growth regulator gave higher LAI one resulted in producing more photosynthetic metabolites which stored in rice organ up to complete heading and then translocation to sink of rice. These results are in congruence with results obtained by Akita (1989), Abouel-Yazied et al. (2012), Wiatrak (2012b), Nayar and Bott (2014) and Niakan and Ahmadi (2014).

Table 5. Leaf area index (LAI) of Sakhal08 rice cultivars as affected by the interaction between different irrigation intervals and growth regulators in 2018 and 2019 seasons

\begin{tabular}{l|c|c|c|c|c|c|c|c}
\hline & \multicolumn{5}{|c|}{$\mathbf{2 0 1 8}$ season } & \multicolumn{4}{c}{ 2019 season } \\
\cline { 2 - 8 } & I1 & I2 & I3 & I4 & I1 & I2 & I3 & I4 \\
\hline (T1) & $4.68 \mathrm{a}-\mathrm{e}$ & $4.48 \mathrm{a}-\mathrm{f}$ & $4.47 \mathrm{a}-\mathrm{f}$ & $4.41 \mathrm{a}-\mathrm{f}$ & $5.01 \mathrm{a}-\mathrm{e}$ & $4.80 \mathrm{a}-\mathrm{f}$ & $4.79 \mathrm{a}-\mathrm{f}$ & $4.70 \mathrm{a}-\mathrm{g}$ \\
(T2) & $5.19 \mathrm{a}-\mathrm{c}$ & $4.58 \mathrm{a}-\mathrm{f}$ & $4.47 \mathrm{a}-\mathrm{f}$ & $4.45 \mathrm{a}-\mathrm{f}$ & $5.51 \mathrm{ab}$ & $4.90 \mathrm{a}-\mathrm{e}$ & $4.80 \mathrm{a}-\mathrm{f}$ & $4.74 \mathrm{a}-\mathrm{g}$ \\
(T3) & $5.37 \mathrm{a}$ & $5.33 \mathrm{ab}$ & $4.81 \mathrm{a}-\mathrm{d}$ & $4.69 \mathrm{a}-\mathrm{e}$ & $5.66 \mathrm{a}$ & $5.13 \mathrm{a}-\mathrm{c}$ & $5.01 \mathrm{a}-\mathrm{d}$ & $4.77 \mathrm{a}-\mathrm{g}$ \\
(T4) & $4.22 \mathrm{a}-\mathrm{f}$ & $3.82 \mathrm{~b}-\mathrm{h}$ & $3.72 \mathrm{c}-\mathrm{j}$ & $3.65 \mathrm{~d}-\mathrm{j}$ & $4.54 \mathrm{~b}-\mathrm{h}$ & $4.15 \mathrm{c}-\mathrm{i}$ & $4.04 \mathrm{~d}-\mathrm{i}$ & $3.97 \mathrm{~d}-\mathrm{j}$ \\
(T5) & $4.28 \mathrm{a}-\mathrm{f}$ & $4.23 \mathrm{a}-\mathrm{f}$ & $4.10 \mathrm{a}-\mathrm{g}$ & $3.81 \mathrm{c}-\mathrm{h}$ & $4.60 \mathrm{~b}-\mathrm{h}$ & $4.56 \mathrm{~b}-\mathrm{h}$ & $4.43 \mathrm{c}-\mathrm{i}$ & $4.14 \mathrm{c}-\mathrm{i}$ \\
(T6) & $4.43 \mathrm{a}-\mathrm{f}$ & $4.37 \mathrm{a}-\mathrm{f}$ & $4.14 \mathrm{a}-\mathrm{g}$ & $3.92 \mathrm{a}-\mathrm{h}$ & $4.76 \mathrm{a}-\mathrm{g}$ & $4.70 \mathrm{a}-\mathrm{g}$ & $4.47 \mathrm{c}-\mathrm{i}$ & $4.24 \mathrm{c}-\mathrm{i}$ \\
(T7) & $3.78 \mathrm{c}-\mathrm{i}$ & $3.58 \mathrm{~d}-\mathrm{k}$ & $3.54 \mathrm{~d}-\mathrm{k}$ & $2.30 \mathrm{ijk}$ & $4.11 \mathrm{c}-\mathrm{i}$ & $3.91 \mathrm{e}-\mathrm{j}$ & $3.87 \mathrm{e}-\mathrm{j}$ & 2.621 \\
(T8) & $3.87 \mathrm{a}-\mathrm{h}$ & $3.76 \mathrm{c}-\mathrm{j}$ & $3.54 \mathrm{~d}-\mathrm{k}$ & $3.08 \mathrm{f}-\mathrm{k}$ & $4.20 \mathrm{c}-\mathrm{i}$ & $4.09 \mathrm{c}-\mathrm{i}$ & $3.87 \mathrm{e}-\mathrm{j}$ & $3.41 \mathrm{i}-1$ \\
(T9) & $4.11 \mathrm{a}-\mathrm{g}$ & $3.77 \mathrm{c}-\mathrm{j}$ & $3.66 \mathrm{~d}-\mathrm{j}$ & $3.27 \mathrm{e}-\mathrm{k}$ & $4.43 \mathrm{c}-\mathrm{i}$ & $4.09 \mathrm{c}-\mathrm{i}$ & $3.98 \mathrm{~d}-\mathrm{j}$ & $3.59 \mathrm{~h}-\mathrm{k}$ \\
(T10) & $3.71 \mathrm{c}-\mathrm{j}$ & $3.29 \mathrm{e}-\mathrm{k}$ & $3.28 \mathrm{e}-\mathrm{k}$ & $2.27 \mathrm{jk}$ & $4.03 \mathrm{~d}-\mathrm{i}$ & $3.62 \mathrm{~h}-\mathrm{k}$ & $3.61 \mathrm{~h}-\mathrm{k}$ & 2.601 \\
(T11) & $3.78 \mathrm{c}-\mathrm{j}$ & $3.40 \mathrm{~d}-\mathrm{k}$ & $3.57 \mathrm{~d}-\mathrm{k}$ & $2.29 \mathrm{ijk}$ & $4.10 \mathrm{c}-\mathrm{i}$ & $3.73 \mathrm{~g}-\mathrm{j}$ & $3.89 \mathrm{e}-\mathrm{j}$ & 2.621 \\
(T12) & $3.78 \mathrm{c}-\mathrm{i}$ & $3.58 \mathrm{~d}-\mathrm{k}$ & $3.53 \mathrm{~d}-\mathrm{k}$ & $2.29 \mathrm{ijk}$ & $4.11 \mathrm{c}-\mathrm{i}$ & $3.91 \mathrm{e}-\mathrm{j}$ & $3.86 \mathrm{e}-\mathrm{j}$ & 2.621 \\
(T13) & $3.46 \mathrm{~d}-\mathrm{k}$ & $2.66 \mathrm{~g}-\mathrm{k}$ & $2.42 \mathrm{~h}-\mathrm{k}$ & $2.12 \mathrm{k}$ & $3.78 \mathrm{f}-\mathrm{j}$ & $2.99 \mathrm{jkl}$ & $2.75 \mathrm{kl}$ & 2.441 \\
\hline
\end{tabular}

I1: irrigation every3-days, I2: irrigation every 6-days, I3: irrigation every 9-days, I4: irrigation every 12days, $\mathrm{T}_{1}: 0.5 \mathrm{ml}$ Crop plus, $\mathrm{T}_{2}: 1.00 \mathrm{ml}$ Crop plus, $\mathrm{T}_{3}: 1.5 \mathrm{ml}$ Crop plus, $\mathrm{T}_{4}: 15 \mathrm{ppm}$ Cytokinin, $\mathrm{T}_{5}: 20$ ppm Cytokinin, $\mathrm{T}_{6}: 25 \mathrm{ppm}$ Cytokinin, $\mathrm{T}_{7}: 15 \mathrm{ppm} \mathrm{ABA}, \mathrm{T}_{8}: 20$ ppm ABA, $\mathrm{T}_{9}: 25 \mathrm{ppm} \mathrm{ABA}, \mathrm{T}_{10}: 1 \mathrm{ml}$ Trafos K, $\mathrm{T}_{11}: 1.5 \mathrm{ml}$ Trafos K, $\mathrm{T}_{12}: 2 \mathrm{ml}$ Trafos K, $\mathrm{T}_{13}$ : Tap water

\section{Chlorophyll content of flag leaf}

Data in Table 4 indicated that irrigation every 3-days produced the greatest chlorophyll content in the flag leaf followed by the irrigation every 6 and 9-days, while irrigation every 12-days gave the lowest value in this aspect. The decreases in chlorophyll content under the irrigation every 12 days could be attributed to water stress under this treatment which cause a decrease in chlorophyll biosciences inside the plant cell and increase the degradation in chlorophyll under the deficiency of water content. Also, the deficiency of water (water stress) inhibited the specific enzymes that are responsible for the biosynthesis of chlorophyll in chloroplasts resulting in a decrease in 
the content of chlorophyll and cause senescence in rice leaves specially flag leaf. These results are in a line with that obtained by Hossain (2001), El- Refaee et al. (2012) and El-Habet (2014).

Data in the same table indicated that the foliar spray of different plant growth biostimulants or regulators (PGRs) caused an increase in chlorophyll content of flag leaf. The highest values were observed when rice was sprayed with Crop plus followed by Cytokinin and ABA, while the lowest value was recorded when the plants were sprayed without growth regulators (control). The highest value of plant growth regulators were recorded by Crop plus when spraying was carried out at a concentration of $1.5 \mathrm{ml} /$ liter water followed by when spraying by the same component but with a concentration of $1 \mathrm{ml} /$ liter at different growth stage of rice plant. These results are in line with that obtained by Gemici et al. (1998, 2002), Wiatrak (2012b), Nayar and Bott (2014) and Niakan and Ahmadi (2014).

Regarding the interaction effect between different irrigation intervals and plant growth regulators and biostimulants in chlorophyll content of flag leaf (Table 6) data showed that spraying with Crop plus at rate $1.5 \mathrm{ml}$ gave the highest chlorophyll content under different water intervals followed by when rice plant treated even with $1 \mathrm{ml}$, $0.5 \mathrm{ml}$ of Crop plus and $25 \mathrm{ppm}$ Cytokinin which come in the second rank while ABA come in the third rank as plant growth regulator under any irrigation intervals time. In contrast the lowest value was recorded by irrigation every 12 days because of the water deficit (water stress) which cause a reduction in chlorophyll. Also, further water stress usually accelerates leaf senescence. In contrast, Crop plus delays leaf senescence due to improving chlorophyll inside the plant cell. These researchers found that Crop plus increased photosynthetic pigments and leaf chlorophyll contents in the plants under study. These results are in harmony with that recorded by Akita (1989), Abouel-Yazied et al. (2012), Wiatrak (2012b), Nayar and Bott (2014) and Niakan and Ahmadi (2014).

Table 6. Chlorophyll content of Sakha108 rice cultivars as affected by the interaction between different irrigation intervals and growth regulators in 2018 and 2019 seasons

\begin{tabular}{l|c|c|c|c|c|c|c|c}
\hline & \multicolumn{5}{|c|}{$\mathbf{2 0 1 8}$ season } & \multicolumn{4}{c}{ 2019 season } \\
\cline { 2 - 8 } & I1 & I2 & I3 & I4 & I1 & I2 & I3 & I4 \\
\hline (T1) & $46.47 \mathrm{bc}$ & $45.67 \mathrm{c}-\mathrm{f}$ & $42.93 \mathrm{i}-1$ & $42.37 \mathrm{k}-\mathrm{m}$ & $45.74 \mathrm{bc}$ & $44.94 \mathrm{c}-\mathrm{f}$ & $42.20 \mathrm{i}-1$ & $41.64 \mathrm{k}-\mathrm{m}$ \\
(T2) & $47.67 \mathrm{~b}$ & $45.83 \mathrm{c}-\mathrm{f}$ & $43.50 \mathrm{~g}-\mathrm{k}$ & $42.60 \mathrm{kl}$ & $46.94 \mathrm{~b}$ & $45.10 \mathrm{c}-\mathrm{f}$ & $42.77 \mathrm{~g}-\mathrm{k}$ & $41.87 \mathrm{kl}$ \\
(T3) & $49.07 \mathrm{a}$ & $46.07 \mathrm{c}-\mathrm{e}$ & $43.63 \mathrm{~g}-\mathrm{k}$ & $42.62 \mathrm{kl}$ & $48.34 \mathrm{a}$ & $45.34 \mathrm{cde}$ & $42.90 \mathrm{~g}-\mathrm{k}$ & $41.89 \mathrm{kl}$ \\
(T4) & $44.37 \mathrm{f}-\mathrm{j}$ & $43.77 \mathrm{~g}-\mathrm{k}$ & $40.87 \mathrm{~m}-\mathrm{o}$ & $40.77 \mathrm{~m}-\mathrm{o}$ & $43.64 \mathrm{f}-\mathrm{j}$ & $43.04 \mathrm{~g}-\mathrm{k}$ & $40.14 \mathrm{mnno}$ & $40.04 \mathrm{~m}-\mathrm{o}$ \\
(T5) & $45.00 \mathrm{c}-\mathrm{g}$ & $44.50 \mathrm{e}-\mathrm{i}$ & $42.83 \mathrm{j}-\mathrm{l}$ & $41.301-\mathrm{n}$ & $44.27 \mathrm{c}-\mathrm{g}$ & $43.77 \mathrm{e}-\mathrm{i}$ & $42.10 \mathrm{kl}$ & $40.571-\mathrm{n}$ \\
(T6) & $46.13 \mathrm{~cd}$ & $44.80 \mathrm{~d}-\mathrm{h}$ & $42.90 \mathrm{i}-1$ & $41.371-\mathrm{n}$ & $45.40 \mathrm{~cd}$ & $44.07 \mathrm{~d}-\mathrm{h}$ & $42.17 \mathrm{i}-1$ & $40.641-\mathrm{n}$ \\
(T7) & $42.57 \mathrm{kl}$ & $40.83 \mathrm{~m}-\mathrm{o}$ & $40.72 \mathrm{~m}-\mathrm{o}$ & $40.60 \mathrm{no}$ & $41.84 \mathrm{kl}$ & $40.10 \mathrm{~m}-\mathrm{o}$ & $39.99 \mathrm{~m}-\mathrm{o}$ & $39.87 \mathrm{no}$ \\
(T8) & $43.20 \mathrm{~h}-\mathrm{k}$ & $40.97 \mathrm{mn}$ & $40.73 \mathrm{~m}-\mathrm{o}$ & $40.63 \mathrm{no}$ & $42.47 \mathrm{~h}-\mathrm{k}$ & $40.24 \mathrm{mn}$ & $39.99 \mathrm{~m}-\mathrm{o}$ & $39.90 \mathrm{no}$ \\
(T9) & $43.37 \mathrm{~h}-\mathrm{k}$ & $41.47 \mathrm{ln}$ & $40.73 \mathrm{~m}-\mathrm{o}$ & $40.73 \mathrm{~m}-\mathrm{o}$ & $42.64 \mathrm{~h}-\mathrm{k}$ & $40.741-\mathrm{n}$ & $39.99 \mathrm{~m}-\mathrm{o}$ & $39.99 \mathrm{~m}-\mathrm{o}$ \\
(T10) & $40.53 \mathrm{no}$ & $40.33 \mathrm{no}$ & $40.17 \mathrm{n}-\mathrm{p}$ & $40.03 \mathrm{n}-\mathrm{p}$ & $39.80 \mathrm{no}$ & $39.60 \mathrm{no}$ & $39.44 \mathrm{n}-\mathrm{p}$ & $39.30 \mathrm{nop}$ \\
(T11) & $40.90 \mathrm{~m}-\mathrm{o}$ & $40.73 \mathrm{~m}-\mathrm{o}$ & $40.27 \mathrm{n}-\mathrm{p}$ & $40.27 \mathrm{n}-\mathrm{p}$ & $40.20 \mathrm{~m}-\mathrm{o}$ & $39.99 \mathrm{~m}-\mathrm{o}$ & $39.54 \mathrm{n}-\mathrm{p}$ & $39.54 \mathrm{nop}$ \\
(T12) & $40.93 \mathrm{~m}-\mathrm{o}$ & $40.83 \mathrm{~m}-\mathrm{o}$ & $40.57 \mathrm{no}$ & $40.27 \mathrm{n}-\mathrm{p}$ & $40.20 \mathrm{~m}-\mathrm{o}$ & $40.10 \mathrm{~m}-\mathrm{o}$ & $39.84 \mathrm{no}$ & $39.54 \mathrm{nop}$ \\
(T13) & $39.93 \mathrm{n}-\mathrm{p}$ & $39.90 \mathrm{n}-\mathrm{p}$ & $39.20 \mathrm{op}$ & $38.67 \mathrm{p}$ & $39.20 \mathrm{n}-\mathrm{p}$ & $39.20 \mathrm{n}-\mathrm{p}$ & $38.47 \mathrm{op}$ & $37.94 \mathrm{p}$ \\
\hline
\end{tabular}

I1: irrigation every3-days, I2: irrigation every 6-days, I3: irrigation every 9-days, I4: irrigation every 12days, $\mathrm{T}_{1}: 0.5 \mathrm{ml}$ Crop plus, $\mathrm{T}_{2}: 1.00 \mathrm{ml}$ Crop plus, $\mathrm{T}_{3}: 1.5 \mathrm{ml}$ Crop plus, $\mathrm{T}_{4}: 15 \mathrm{ppm}$ Cytokinin, $\mathrm{T}_{5}: 20$ ppm Cytokinin, $\mathrm{T}_{6}: 25 \mathrm{ppm}$ Cytokinin, $\mathrm{T}_{7}: 15 \mathrm{ppm}$ ABA, $\mathrm{T}_{8}: 20 \mathrm{ppm}$ ABA, $\mathrm{T}_{9}: 25 \mathrm{ppm}$ ABA, $\mathrm{T}_{10}: 1 \mathrm{ml}$ Trafos K, $\mathrm{T}_{11}: 1.5 \mathrm{ml}$ Trafos K, $\mathrm{T}_{12}: 2 \mathrm{ml}$ Trafos K, $\mathrm{T}_{13}$ : Tap water 


\section{Dry matter production $\mathrm{g} / \mathrm{m}^{2}$}

Results in Table 4 indicated that dry matter accumulation was significantly higher under different water intervals, whereas the increasing in dry matter content was obtained when rice was irrigated every 3 days followed by irrigation every 6 days, while the lowest value was obtained with the irrigation every 12 days in both seasons of study. Similar results were reported by Islam et al. (1994a, b), Wu et al. (2011) and Li et al. (2015). This result might be due to the increase in number of tillers consequently increased number and area of leaves resulted in increase in photosynthesis which accumulate higher amount of dry matter production.

Data in the same table revealed that spraying by any plant biostimulated and growth regulators caused an increase in dry matter production as compared with control (Tap water). The highest dry matter production was found when rice plants sprayed with any concentration of Crop plus $(1.5,1.00$ and $0.5 \mathrm{ml} /$ liter water) and recorded nearly the same value of dry matter production followed by spraying with 25 ppm of Cytokinin as plant regulators which came in second rank after Crop plus. Similar results were observed in the two seasons of the study. These results are mainly attributed to the fact that spraying with growth regulators and biostimulants at various physiological growth stages encourage plant photosynthesis during plant growth through increasing all vegetative growth characters which led finally to raise dry weight accumulation. These results are in a good compatibility with those obtained by Gemici et al. (1998, 2002), Houssien et al. (2011), Prajapati and Modi (2012) and Abdel-Megeed et al. (2017).

Regarding the interaction effect among irrigation treatments and plant growth regulators (PGR) and biostimulants, data in Table 7 show that foliar application of any biostimulated of plant growth regulators at any different dose of them gave positive result of dry matter production under different water intervals (3, 6, 9 and 12-days) in the two studied seasons. It can be easily observed that Crop plus with $1.5 \mathrm{ml}$ came in the first rank and recorded the highest dry matter production under all different irrigation treatments followed by spraying the same component of crop plus at different concentration $1 \mathrm{ml}$ and $0.5 \mathrm{ml}$. While Cytokinin at the rate of $25 \mathrm{ppm}$ came in the second rank after Crop plus as plant regulator. It might be due to the role of these substances to help the plant for keeping the water inside the cell longer consequently extending the period of irrigation intervals that led to save reasonable amount of irrigation water. These results are in good agreement with those reported by Akita (1989), Gemici et al. (1998), Abouel-Yazied et al. (2012), Prajapati and Modi (2012) and Abdel-Megeed et al. (2017).

\section{Number of tiller/m² at harvest}

Data in Table 8 demonstrated that irrigation every 3-days showed superiority of number of tillers $/ \mathrm{m}^{2}$ than irrigation every 12-days which produced the lowest value in this respect. These results were true in the two seasons of study. It might be due to the decrease in number of tillers as result to water deficiency (water stress) under irrigation every 12-days beside the negative effect of water stress on the growth.

The results are mainly due to the vigor's of rice variety under this study (genetic background). These results are in line with that reported by Yan et al. (2015), Wu et al. (2018) and Yamaguchi et al. (2019). 


$$
\text { - } 2867 \text { - }
$$

Table 7. Dry matter production (DM) $\left(\mathrm{g} / \mathrm{m}^{2}\right)$ of Sakhal08 rice cultivars as affected by the interaction between different irrigation intervals and growth regulators in 2018 and 2019 seasons

\begin{tabular}{c|c|c|c|c|c|c|c|c}
\hline & \multicolumn{9}{|c|}{$\mathbf{2 0 1 8}$ season } & \multicolumn{4}{c}{ 2019 season } \\
\cline { 2 - 9 } & I1 & I2 & I3 & I4 & I1 & I2 & I3 & I4 \\
\hline (T1) & $1715.8 \mathrm{ab}$ & $1631.5 \mathrm{~cd}$ & $1575.5 \mathrm{ef}$ & $1290.6 \mathrm{k}-\mathrm{n}$ & $1720.3 \mathrm{ab}$ & $1635.9 \mathrm{~cd}$ & $1579.9 \mathrm{ef}$ & $1295.0 \mathrm{k}-\mathrm{n}$ \\
(T2) & $1716.3 \mathrm{ab}$ & $1631.7 \mathrm{~cd}$ & $1583.1 \mathrm{e}$ & $1309.6 \mathrm{j}-\mathrm{m}$ & $1720.8 \mathrm{ab}$ & $1636.1 \mathrm{~cd}$ & $1587.5 \mathrm{e}$ & $1314.0 \mathrm{j}-\mathrm{m}$ \\
(T3) & $1749.5 \mathrm{a}$ & $1632.2 \mathrm{~cd}$ & $1583.7 \mathrm{e}$ & $1326.8 \mathrm{i}-\mathrm{k}$ & $1754.0 \mathrm{a}$ & $1636.7 \mathrm{~cd}$ & $1588.1 \mathrm{e}$ & $1331.3 \mathrm{i}-\mathrm{k}$ \\
(T4) & $1628.6 \mathrm{~cd}$ & $1389.2 \mathrm{~h}$ & $1336.9 \mathrm{ij}$ & $1280.31-\mathrm{o}$ & $1633.0 \mathrm{~cd}$ & $1393.7 \mathrm{~h}$ & $1341.4 \mathrm{ij}$ & $1284.81-\mathrm{o}$ \\
(T5) & $1647.7 \mathrm{c}$ & $1599.1 \mathrm{de}$ & $1395.6 \mathrm{~h}$ & $1284.7 \mathrm{k}-\mathrm{n}$ & $1652.2 \mathrm{c}$ & $1603.5 \mathrm{de}$ & $1400.0 \mathrm{~h}$ & $1289.1 \mathrm{k}-\mathrm{n}$ \\
(T6) & $1689.1 \mathrm{~b}$ & $1530.1 \mathrm{~g}$ & $1536.9 \mathrm{fg}$ & $1286.7 \mathrm{k}-\mathrm{n}$ & $1693.5 \mathrm{~b}$ & $1534.5 \mathrm{~g}$ & $1541.4 \mathrm{fg}$ & $1291.2 \mathrm{k}-\mathrm{n}$ \\
(T7) & $1584.6 \mathrm{e}$ & $1363.1 \mathrm{hi}$ & $1144.7 \mathrm{r}$ & $1103.7 \mathrm{~s}$ & $1589.0 \mathrm{e}$ & $1367.5 \mathrm{hi}$ & $1149.2 \mathrm{r}$ & $1108.1 \mathrm{~s}$ \\
(T8) & $1599.3 \mathrm{de}$ & $1382.0 \mathrm{~h}$ & $1327.4 \mathrm{i}-\mathrm{k}$ & $1267.6 \mathrm{~m}-\mathrm{p}$ & $1603.8 \mathrm{de}$ & $1386.4 \mathrm{~h}$ & $1331.9 \mathrm{i}-\mathrm{k}$ & $1272.1 \mathrm{~m}-\mathrm{p}$ \\
(T9) & $1600.3 \mathrm{de}$ & $1384.2 \mathrm{~h}$ & $1336.8 \mathrm{ij}$ & $1277.61-\mathrm{p}$ & $1604.8 \mathrm{de}$ & $1388.7 \mathrm{~h}$ & $1341.3 \mathrm{ij}$ & $1282.01-\mathrm{p}$ \\
(T10) & $1315.7 \mathrm{j}-1$ & $1235.6 \mathrm{pq}$ & $1057.8 \mathrm{t}$ & $1052.5 \mathrm{t}$ & $1320.1 \mathrm{j}-1$ & $1240.0 \mathrm{pq}$ & $1062.3 \mathrm{t}$ & $1056.9 \mathrm{t}$ \\
(T11) & $1338.9 \mathrm{ij}$ & $1239.3 \mathrm{o}-\mathrm{q}$ & $1058.2 \mathrm{t}$ & $1053.4 \mathrm{t}$ & $1343.4 \mathrm{ij}$ & $1243.8 \mathrm{o}-\mathrm{q}$ & $1062.6 \mathrm{t}$ & $1057.9 \mathrm{t}$ \\
(T12) & $1566.4 \mathrm{efg}$ & $1246.2 \mathrm{n}-\mathrm{q}$ & $1073.3 \mathrm{st}$ & $1064.7 \mathrm{st}$ & $1570.9 \mathrm{e}-\mathrm{g}$ & $1250.6 \mathrm{n}-\mathrm{q}$ & $1077.8 \mathrm{st}$ & $1069.1 \mathrm{st}$ \\
(T13) & $1314.7 \mathrm{jkl}$ & $1218.9 \mathrm{q}$ & $1044.7 \mathrm{t}$ & $1028.2 \mathrm{t}$ & $1319.1 \mathrm{jkl}$ & $1223.4 \mathrm{q}$ & $1049.1 \mathrm{t}$ & $1032.6 \mathrm{t}$ \\
\hline
\end{tabular}

Table 8. Number of tiller $/ \mathrm{m}^{2}$, number of panicle/ $\mathrm{m}^{2}$ and number of filled grain/panicle at harvest of Sakha108 rice cultivars as affected by different irrigation intervals and growth regulators during 2018 and 2019 season

\begin{tabular}{|c|c|c|c|c|c|c|}
\hline \multirow[b]{2}{*}{ Treatments } & \multicolumn{3}{|c|}{2018} & \multicolumn{3}{|c|}{2019} \\
\hline & $\begin{array}{c}\text { No. of } \\
\text { tiller } / \mathbf{m}^{2}\end{array}$ & $\begin{array}{c}\text { No. of } \\
\text { panicle/m² }\end{array}$ & $\begin{array}{c}\text { No. of filled } \\
\text { grain }\end{array}$ & $\begin{array}{c}\text { No. of } \\
\text { tiller } / \mathbf{m}^{2}\end{array}$ & $\begin{array}{c}\text { No. of } \\
\text { panicle/m² }\end{array}$ & $\begin{array}{c}\text { No. of filled } \\
\text { grain }\end{array}$ \\
\hline Irrigation interval (A): & & & & & & \\
\hline$\left(\mathrm{I}_{1}\right)$ & $490.77 \mathrm{a}$ & $466.90 \mathrm{a}$ & $148.84 \mathrm{a}$ & $495.36 \mathrm{a}$ & $471.49 \mathrm{a}$ & $142.01 \mathrm{a}$ \\
\hline$\left(\mathrm{I}_{2}\right)$ & $460.19 b$ & $429.23 b$ & $145.68 b$ & $464.78 b$ & $433.82 b$ & $140.32 b$ \\
\hline$\left(\mathrm{I}_{3}\right)$ & $442.94 \mathrm{c}$ & $414.62 \mathrm{c}$ & $143.37 \mathrm{c}$ & $447.53 c$ & $419.21 \mathrm{c}$ & $138.86 \mathrm{c}$ \\
\hline$\left(\mathrm{I}_{4}\right)$ & $421.40 d$ & $402.83 \mathrm{c}$ & $138.89 d$ & 425.99d & $407.42 d$ & $136.89 \mathrm{~d}$ \\
\hline $\begin{array}{c}\text { F. } \\
\text { Test }\end{array}$ & $* *$ & $* *$ & $* *$ & $* *$ & $* *$ & $* *$ \\
\hline$\frac{\text { Growth regulates }}{\text { treatment }(\mathrm{B})}$ & & & & & & \\
\hline$\frac{(\mathrm{T} 1)}{}$ & $513.13 b c$ & $475.00 \mathrm{bc}$ & $149.24 \mathrm{c}$ & $517.72 b c$ & $479.59 \mathrm{bc}$ & $144.03 \mathrm{c}$ \\
\hline (T2) & $530.00 \mathrm{ab}$ & $483.75 b$ & $152.13 b$ & $534.59 \mathrm{ab}$ & $488.34 b$ & $147.08 b$ \\
\hline (T3) & $538.75 \mathrm{a}$ & $500.00 \mathrm{a}$ & $155.28 \mathrm{a}$ & $543.34 \mathrm{a}$ & $504.59 a$ & $148.28 \mathrm{a}$ \\
\hline (T4) & $474.56 \mathrm{ef}$ & $450.00 \mathrm{~h}$ & $144.28 \mathrm{e}$ & $479.15 \mathrm{ef}$ & $454.59 \mathrm{ef}$ & $142.40 \mathrm{e}$ \\
\hline (T5) & $488.75 \mathrm{de}$ & $457.50 \mathrm{~d}$ & $145.82 d$ & 493.34de & $462.09 \mathrm{de}$ & $143.00 \mathrm{~d}$ \\
\hline (T6) & $502.50 \mathrm{~cd}$ & $468.75 \mathrm{~cd}$ & $148.54 \mathrm{c}$ & $507.09 \mathrm{~cd}$ & $473.34 \mathrm{~cd}$ & $143.33 d$ \\
\hline (T7) & $436.25 \mathrm{~g}$ & $422.44 \mathrm{f}$ & $141.69 f$ & $440.84 \mathrm{~g}$ & $427.03 \mathrm{~h}$ & 137.281 \\
\hline (T8) & $455.00 \mathrm{fg}$ & $432.50 \mathrm{ef}$ & $143.25 \mathrm{e}$ & $459.59 \mathrm{fg}$ & $437.09 \mathrm{gh}$ & $140.10 \mathrm{~g}$ \\
\hline (T9) & $458.75 \mathrm{fg}$ & $441.25 \mathrm{e}$ & $143.94 \mathrm{e}$ & $463.34 \mathrm{fg}$ & $445.84 \mathrm{fg}$ & $141.30 \mathrm{f}$ \\
\hline (T10) & $372.50 \mathrm{~h}$ & $355.44 \mathrm{~h}$ & $135.89 \mathrm{~h}$ & $377.09 \mathrm{~h}$ & $360.03 \mathrm{j}$ & $130.95 \mathrm{k}$ \\
\hline (T11) & $377.06 \mathrm{~h}$ & $362.50 \mathrm{~d}$ & $139.13 \mathrm{~g}$ & $381.65 \mathrm{~h}$ & $367.09 \mathrm{ij}$ & $132.63 \mathrm{j}$ \\
\hline (T12) & $387.50 \mathrm{~h}$ & $371.25 \mathrm{~cd}$ & $140.18 \mathrm{~g}$ & $392.09 \mathrm{~h}$ & $375.84 \mathrm{i}$ & $134.63 \mathrm{i}$ \\
\hline (T13) & $365.00 \mathrm{~h}$ & $348.75 \mathrm{f}$ & $135.15 \mathrm{~h}$ & $369.59 \mathrm{~h}$ & $353.34 \mathrm{j}$ & 128.751 \\
\hline F. Test & ** & $* *$ & $* *$ & $* *$ & $* *$ & $* *$ \\
\hline Interaction: $\mathrm{AXB}$ & *** & $* *$ & $* *$ & $* *$ & $* *$ & $* *$ \\
\hline
\end{tabular}

I1: Continuous flooded, I2: irrigation every 3-days, I3: irrigation every 6-days, I4: irrigation every 9days, $\mathrm{T}_{1}: 0.5 \mathrm{ml}$ Crop plus, $\mathrm{T}_{2}: 1.00 \mathrm{ml}$ Crop plus, $\mathrm{T}_{3}: 1.5 \mathrm{ml}$ Crop plus, $\mathrm{T}_{4}: 15 \mathrm{ppm}$ Cytokinin, $\mathrm{T}_{5}: 20$ ppm Cytokinin, $\mathrm{T}_{6}: 25 \mathrm{ppm}$ Cytokinin, $\mathrm{T}_{7}: 15 \mathrm{ppm} \mathrm{ABA}, \mathrm{T}_{8}: 20 \mathrm{ppm}$ ABA, $\mathrm{T}_{9}: 25 \mathrm{ppm}$ ABA, $\mathrm{T}_{10}: 1 \mathrm{ml}$ Trafos K, $\mathrm{T}_{11}: 1.5 \mathrm{ml}$ Trafos K, $\mathrm{T}_{12}: 2 \mathrm{ml}$ Trafos K, $\mathrm{T}_{13}$ : Tap water 
From the result presented in Table 8 spraying Crop plus recorded the highest number of tillers $/ \mathrm{m}^{2}$ followed by Cytokinin, ABA and Trafos $\mathrm{K}$ which came in the last rank. Whereas, control gave the lowest value of number of tillers $/ \mathrm{m}^{2}$ in both seasons. It can be easily noticed that the application of the plant growth regulating substance caused an increase in number of tillers as compared with control treatments (Tap water).

The treatments which had not received any plant growth regulator produced the lowest values in this aspect. These might be due to the encouraging of the emergence of more number of tillers from up ground nodes to when the rice plant treated by PGRs at different growth date of rice plant. These results could be mainly attributed to the fact that spraying with any PGRs improved the number of tillers $/ \mathrm{m}^{2}$ as compared with control treatments (Tap water only). These results are in a good coincidence with that obtained by Gemici et al. (1998, 2002), Craigie (2011), Abubakar (2012), Canady (2012) and Bhattacharya (2019).

The interaction between different irrigation intervals and different PGRs had a significant influence on number of tiller/ $\mathrm{m}^{2}$. From the results presented in Table 9, it could be concluded that plants which treated by Crop plus produced the highest number of tillers $/ \mathrm{m}^{2}$ under different water irrigation every 3, 6, 9 and 12 days, followed by Cytokinin and ABA treatments, while Trafos $\mathrm{K}$ treatment came in the last rank of plant growth regulator. While the lowest number of tillers were obtained when rice plant was treated by tap water under irrigation every 12 days.

Table 9. Number of tiller $/ \mathrm{m}^{2}$, number of panicle $/ \mathrm{m}^{2}$ and number of filled grain/panicle at harvest as affected by the interaction between different irrigation intervals and growth regulators in 2018 and 2019 seasons

\begin{tabular}{c|c|c|c|c|c|c|c|c}
\hline & \multicolumn{7}{|c|}{ 2018 season } & \multicolumn{4}{c}{ 2019 season } \\
\cline { 2 - 8 } & I1 & I2 & I3 & I4 & I1 & I2 & I3 & I4 \\
\hline (T1) & $565.00 \mathrm{a}$ & $512.50 \mathrm{bc}$ & $500.00 \mathrm{~b}-\mathrm{f}$ & $475.00 \mathrm{e}-\mathrm{h}$ & $569.59 \mathrm{a}$ & $517.09 \mathrm{~b}-\mathrm{e}$ & $504.59 \mathrm{~b}-\mathrm{f}$ & $479.59 \mathrm{e}-\mathrm{h}$ \\
(T2) & $570.00 \mathrm{a}$ & $550.00 \mathrm{ab}$ & $515.00 \mathrm{~b}-\mathrm{e}$ & $485.00 \mathrm{~d}-\mathrm{g}$ & $574.59 \mathrm{a}$ & $554.59 \mathrm{ab}$ & $519.59 \mathrm{be}$ & $489.59 \mathrm{~d}-\mathrm{g}$ \\
(T3) & $575.00 \mathrm{a}$ & $570.00 \mathrm{a}$ & $515.00 \mathrm{~b}-\mathrm{e}$ & $495.00 \mathrm{c}-\mathrm{f}$ & $579.59 \mathrm{a}$ & $574.59 \mathrm{a}$ & $519.59 \mathrm{be}$ & $499.59 \mathrm{c}-\mathrm{f}$ \\
(T4) & $495.00 \mathrm{c}-\mathrm{f}$ & $480.00 \mathrm{~d}-\mathrm{h}$ & $478.25 \mathrm{~d}-\mathrm{h}$ & $445.00 \mathrm{f}-\mathrm{j}$ & $499.59 \mathrm{c}-\mathrm{f}$ & $484.59 \mathrm{~d}-\mathrm{h}$ & $482.84 \mathrm{~d}-\mathrm{h}$ & $449.59 \mathrm{f}-\mathrm{j}$ \\
(T5) & $530.00 \mathrm{a}-\mathrm{d}$ & $495.00 \mathrm{c}-\mathrm{f}$ & $485.00 \mathrm{~d}-\mathrm{g}$ & $445.00 \mathrm{f}-\mathrm{j}$ & $534.59 \mathrm{a}-\mathrm{d}$ & $499.59 \mathrm{c}-\mathrm{f}$ & $489.59 \mathrm{~d}-\mathrm{g}$ & $449.59 \mathrm{f}-\mathrm{j}$ \\
(T6) & $540.00 \mathrm{a}-\mathrm{c}$ & $500.00 \mathrm{~b}-\mathrm{f}$ & $500.00 \mathrm{~b}-\mathrm{f}$ & $470.00 \mathrm{e}-\mathrm{h}$ & $544.59 \mathrm{a}-\mathrm{c}$ & $504.59 \mathrm{~d}-\mathrm{f}$ & $504.59 \mathrm{~b}-\mathrm{f}$ & $474.59 \mathrm{e}-\mathrm{h}$ \\
(T7) & $460.00 \mathrm{e}-\mathrm{h}$ & $450.00 \mathrm{f}-\mathrm{i}$ & $430.00 \mathrm{gj}$ & $405.00 \mathrm{i}-\mathrm{k}$ & $464.59 \mathrm{e}-\mathrm{h}$ & $454.59 \mathrm{f}-\mathrm{i}$ & $434.59 \mathrm{~g}-\mathrm{j}$ & $409.59 \mathrm{i}-\mathrm{k}$ \\
(T8) & $470.00 \mathrm{e}-\mathrm{h}$ & $470.00 \mathrm{e}-\mathrm{h}$ & $455.00 \mathrm{f}-\mathrm{i}$ & $425.00 \mathrm{~h}-\mathrm{j}$ & $474.59 \mathrm{e}-\mathrm{h}$ & $474.59 \mathrm{e}-\mathrm{h}$ & $459.59 \mathrm{f}-\mathrm{i}$ & $429.59 \mathrm{~h}-\mathrm{j}$ \\
(T9) & $475.00 \mathrm{e}-\mathrm{h}$ & $470.00 \mathrm{e}-\mathrm{h}$ & $465.00 \mathrm{eh}$ & $425.00 \mathrm{~h}-\mathrm{j}$ & $479.59 \mathrm{e}-\mathrm{h}$ & $474.59 \mathrm{e}-\mathrm{h}$ & $469.59 \mathrm{e}-\mathrm{h}$ & $429.59 \mathrm{~h}-\mathrm{j}$ \\
(T10) & $425.00 \mathrm{~h}-\mathrm{j}$ & $365.00 \mathrm{kl}$ & 350.001 & $350.00 \mathrm{l}$ & $429.59 \mathrm{~h}-\mathrm{j}$ & $369.59 \mathrm{kl}$ & 354.591 & 354.591 \\
(T11) & $435.00 \mathrm{~g}-\mathrm{j}$ & $365.00 \mathrm{kl}$ & $355.00 \mathrm{kl}$ & $353.25 \mathrm{kl}$ & $439.59 \mathrm{~g}-\mathrm{j}$ & $369.59 \mathrm{kl}$ & $359.59 \mathrm{kl}$ & $357.84 \mathrm{kl}$ \\
(T12) & $435.00 \mathrm{~g}-\mathrm{j}$ & $395.00 \mathrm{k} \mathrm{l}$ & $360.00 \mathrm{kl}$ & $360.00 \mathrm{kl}$ & $439.59 \mathrm{~g}-\mathrm{j}$ & $399.59 \mathrm{jkl}$ & $364.59 \mathrm{kl}$ & $364.59 \mathrm{kl}$ \\
(T13) & $405.00 \mathrm{i}-\mathrm{k}$ & $360.00 \mathrm{kl}$ & 350.001 & 345.001 & $409.59 \mathrm{i}-\mathrm{k}$ & $364.59 \mathrm{kl}$ & 354.591 & 349.591 \\
\hline
\end{tabular}

I1: irrigation every 3-days, I2: irrigation every 6-days, I3: irrigation every 9-days, I4: irrigation every 12-days, $\mathrm{T}_{1}: 0.5 \mathrm{ml}$ Crop plus, $\mathrm{T}_{2}: 1.00 \mathrm{ml}$ Crop plus, $\mathrm{T}_{3}: 1.5 \mathrm{ml}$ Crop plus, $\mathrm{T}_{4}: 15 \mathrm{ppm}$ Cytokinin, $\mathrm{T}_{5}$ : $20 \mathrm{ppm}$ Cytokinin, $\mathrm{T}_{6}: 25 \mathrm{ppm}$ Cytokinin, $\mathrm{T}_{7}: 15 \mathrm{ppm} \mathrm{ABA}, \mathrm{T}_{8}: 20 \mathrm{ppm} \mathrm{ABA,} \mathrm{T}_{9}: 25 \mathrm{ppm}$ ABA, $\mathrm{T}_{10}: 1$ $\mathrm{ml}$ Trafos $\mathrm{K}, \mathrm{T}_{11}: 1.5 \mathrm{ml}$ Trafos K, $\mathrm{T}_{12}: 2 \mathrm{ml}$ Trafos K, $\mathrm{T}_{13}$ : Tap water

Also, data in the same table showed that rice plants which irrigated every 3 days and treated with different dose of Crop plus and $25 \mathrm{ppm}$ of Cytokinin recorded nearly equal number of tillers $/ \mathrm{m}^{2}$. Nearly of the same values of number of tillers $/ \mathrm{m}^{2}$ were recorded when rice plants were irrigated every 8 days and sprayed by the rate of $1.5,1.0$ and 0.5 ppm of Crop plus and 25 ppm Cytokinin without any significant difference between 
them. It means that tested rice sprayed by Crop plus led to extend the irrigation interval from 3-days up to every 9 days consequently saving reasonable amount of irrigation water without significant reduction in the sink capacity (No. of tiller). While the lowest value of number of tillers $/ \mathrm{m}^{2}$ were found with irrigation every 12 days under control treatment (without any spray). Such findings had also been pointed out by Gemici (1993, 1998, 2002), Craigie (2011), Abubakar (2012), Canady (2012) and Bhattacharya (2019).

\section{No. of panicles $/ \mathrm{m}^{2}$}

Data in Table 8 clarified that irrigation every 3-days showed superiority of number of panicle $/ \mathrm{m}^{2}$ than irrigation every 12-days which produced the lowest value in this respect. These results were true in both seasons of study. This might be due to the decrease in number of panicle as result to water deficiency (water stress) under irrigation every 12-days beside the negative effect of water stress on the growth and initiation of panicles as a result to the reduction in phytochrome hormones that responsible for flowering. Also, Hossain (2001), El- Refaee et al. (2012), El-Habet (2014) and Abdel-Megeed et al. (2017) found significant reductions in panicle numbers when rice imposed to water stress at tillering stage. The results are mainly due to the vigor of Sakha108 rice variety under this study (genetic background).

From the result presented in Table 8 spraying Crop plus recorded the highest number of panicle $/ \mathrm{m}^{2}$ followed by Cytokinin, $\mathrm{ABA}$ and Trafos $\mathrm{K}$ which came in the last rank. Whereas, control gave the lowest value of number of panicle $/ \mathrm{m}^{2}$ in both seasons. It can be easily noticed that the application of the plant growth regulating substance caused an increase in number of panicle as compared with control treatments (Tap water).

The treatments which did not involve plant growth regulators produced the lowest values in this aspect. These might be due to the encouraging of the emergence of more number of panicle from up ground nodes to when the rice plant treated by PGRs at different growth date of rice plant. These results could be mainly attributed to the fact that spraying with any PGRs improved the number of panicle $/ \mathrm{m}^{2}$ as compared with control treatments (Tap water only). These results are in line with that obtained by Akita (1989), Abouel-Yazied et al. (2012), Pospíšilová et al. (1993, 2000), Karimi et al. (2012) and Abdel-Megeed et al. (2017).

The interaction between different irrigation intervals and different PGRs had a significant influence on number of panicle $/ \mathrm{m}^{2}$. From the results presented in Table 10, it could be concluded that plants which were treated by Crop plus produced the highest number of panicle $/ \mathrm{m}^{2}$ under different water irrigation every 3, 6, 9 and 12 days, followed by those treated by Cytokinin and ABA, while those treated by Trafos K came in the last rank of plant growth regulators. While the lowest number of panicle were obtained when rice plant was treated by tap water under irrigation every 12 days.

Data in the same table showed also, that rice plants which were irrigated every 3 days and treated with different dose of Crop plus and $25 \mathrm{ppm}$ of Cytokinin recoded the same number of panicle $/ \mathrm{m}^{2}$. Nearly the same values of number of panicle $/ \mathrm{m}^{2}$ were recorded when rice plants were irrigated every 8 days and sprayed with $1.5,1.0$ and 0.5 ppm of Crop plus and 25 ppm Cytokinin without any significant difference between them. It means that tested rice sprayed by Crop plus led to extend the irrigation interval from 3-days up to every 9 days consequently saving reasonable amount of irrigation water without significant reduction in the sink capacity (No. of panicle). While the lowest value of number of panicle $/ \mathrm{m}^{2}$ were found with irrigation every 12 days under 
control treatment (without any spray). Such findings had also been pointed out by Pospíšilová et al. (1993, 2000), Karimi et al. (2012) and Abdel-Megeed et al. (2017).

Table 10. Number of panicle/ $m^{2}$ at harvest as affected by the interaction between different irrigation intervals and growth regulators in 2018 and 2019 seasons

\begin{tabular}{c|c|c|c|c|c|c|c|c}
\hline & \multicolumn{7}{|c|}{ 2018 season } & \multicolumn{4}{c}{ 2019 season } \\
\cline { 2 - 9 } & I1 & I2 & I3 & I4 & I1 & I2 & I3 & I4 \\
\hline (T1) & $520.00 \mathrm{bc}$ & $470.00 \mathrm{~d}-\mathrm{h}$ & $460.00 \mathrm{f}-\mathrm{i}$ & $450.00 \mathrm{~g}-\mathrm{k}$ & $524.59 \mathrm{bc}$ & $474.59 \mathrm{~d}-\mathrm{h}$ & $464.59 \mathrm{f}-\mathrm{i}$ & $454.59 \mathrm{~g}-\mathrm{k}$ \\
(T2) & $545.00 \mathrm{ab}$ & $470.00 \mathrm{~d}-\mathrm{h}$ & $465.00 \mathrm{e}-\mathrm{i}$ & $455.00 \mathrm{~g}-\mathrm{j}$ & $549.59 \mathrm{ab}$ & $474.59 \mathrm{~d}-\mathrm{h}$ & $469.59 \mathrm{e}-\mathrm{i}$ & $459.59 \mathrm{~g}-\mathrm{j}$ \\
(T3) & $550.00 \mathrm{a}$ & $495.00 \mathrm{cde}$ & $490.00 \mathrm{c}-\mathrm{f}$ & $465.00 \mathrm{e}-\mathrm{i}$ & $554.59 \mathrm{a}$ & $499.59 \mathrm{cde}$ & $494.59 \mathrm{c}-\mathrm{f}$ & $469.59 \mathrm{e}-\mathrm{i}$ \\
(T4) & $475.00 \mathrm{~d}-\mathrm{g}$ & $460.00 \mathrm{f}-\mathrm{i}$ & $440.00 \mathrm{~s}$ & $425.00 \mathrm{j}-\mathrm{m}$ & $479.59 \mathrm{~d}-\mathrm{f}$ & $464.59 \mathrm{f}-\mathrm{i}$ & $444.59 \mathrm{~h}-\mathrm{k}$ & $429.59 \mathrm{j}-\mathrm{m}$ \\
(T5) & $500.00 \mathrm{~cd}$ & $465.00 \mathrm{e}-\mathrm{i}$ & $440.00 \mathrm{~h}-\mathrm{k}$ & $425.00 \mathrm{j}-\mathrm{m}$ & $504.59 \mathrm{~cd}$ & $469.59 \mathrm{e}-\mathrm{i}$ & $444.59 \mathrm{~h}-\mathrm{k}$ & $429.59 \mathrm{j}-\mathrm{m}$ \\
(T6) & $500.00 \mathrm{~cd}$ & $470.00 \mathrm{~d}-\mathrm{i}$ & $460.00 \mathrm{f}-\mathrm{i}$ & $445.00 \mathrm{~g}-\mathrm{k}$ & $504.59 \mathrm{~cd}$ & $474.59 \mathrm{~d}-\mathrm{h}$ & $464.59 \mathrm{f}-\mathrm{i}$ & $449.59 \mathrm{~g}-\mathrm{k}$ \\
(T7) & $454.75 \mathrm{~g}-\mathrm{j}$ & $435.00 \mathrm{i}-1$ & $405.001-\mathrm{n}$ & $395.00 \mathrm{mn}$ & $459.34 \mathrm{~g}-\mathrm{j}$ & $439.59 \mathrm{i}-1$ & $409.591-\mathrm{n}$ & $399.59 \mathrm{mn}$ \\
(T8) & $455.00 \mathrm{~g}-\mathrm{j}$ & $435.00 \mathrm{i}-1$ & $420.00 \mathrm{k}-\mathrm{m}$ & $420.00 \mathrm{k}-\mathrm{m}$ & $459.59 \mathrm{~g}-\mathrm{j}$ & $439.59 \mathrm{i}-1$ & $424.59 \mathrm{k}-\mathrm{m}$ & $424.59 \mathrm{k}-\mathrm{m}$ \\
(T9) & $460.00 \mathrm{f}-\mathrm{i}$ & $445.00 \mathrm{~g}-\mathrm{k}$ & $435.00 \mathrm{i}-1$ & $425.00 \mathrm{j}-\mathrm{m}$ & $464.59 \mathrm{f}-\mathrm{i}$ & $449.59 \mathrm{~g}-\mathrm{k}$ & $439.59 \mathrm{i}-1$ & $429.59 \mathrm{j}-\mathrm{m}$ \\
(T10) & $405.001-\mathrm{n}$ & $350.00 \mathrm{o}-\mathrm{q}$ & $340.00 \mathrm{p}-\mathrm{r}$ & $326.75 \mathrm{qr}$ & $409.591-\mathrm{n}$ & $354.59 \mathrm{o}-\mathrm{q}$ & $344.59 \mathrm{p}-\mathrm{r}$ & $331.34 \mathrm{qr}$ \\
(T11) & $405.001-\mathrm{n}$ & $360.00 \mathrm{op}$ & $345.00 \mathrm{o}-\mathrm{r}$ & $340.00 \mathrm{~s}$ & $409.591-\mathrm{n}$ & $364.59 \mathrm{op}$ & $349.59 \mathrm{o}-\mathrm{r}$ & $344.59 \mathrm{pqr}$ \\
(T12) & $405.001-\mathrm{n}$ & $375.00 \mathrm{no}$ & $355.00 \mathrm{o}-\mathrm{q}$ & $350.00 \mathrm{opq}$ & $409.591-\mathrm{n}$ & $379.59 \mathrm{no}$ & $359.59 \mathrm{o}-\mathrm{q}$ & $354.59 \mathrm{opq}$ \\
(T13) & $395.00 \mathrm{mn}$ & $350.00 \mathrm{opq}$ & $335.00 \mathrm{pqr}$ & $315.00 \mathrm{r}$ & $399.59 \mathrm{mn}$ & $354.59 \mathrm{opq}$ & $339.59 \mathrm{pqr}$ & $319.59 \mathrm{r}$ \\
\hline
\end{tabular}

I1: irrigation every 3-days, I2: irrigation every 6-days, I3: irrigation every 9-days, I4: irrigation every 12-days, $\mathrm{T}_{1}: 0.5 \mathrm{ml}$ Crop plus, $\mathrm{T}_{2}: 1.00 \mathrm{ml}$ Crop plus, $\mathrm{T}_{3}: 1.5 \mathrm{ml}$ Crop plus, $\mathrm{T}_{4}: 15 \mathrm{ppm}$ Cytokinin, $\mathrm{T}_{5}$ : $20 \mathrm{ppm}$ Cytokinin, $\mathrm{T}_{6}: 25 \mathrm{ppm}$ Cytokinin, $\mathrm{T}_{7}: 15 \mathrm{ppm} \mathrm{ABA}, \mathrm{T}_{8}: 20 \mathrm{ppm} \mathrm{ABA,} \mathrm{T}_{9}: 25 \mathrm{ppm}$ ABA, $\mathrm{T}_{10}: 1$ $\mathrm{ml}$ Trafos K, $\mathrm{T}_{11}: 1.5 \mathrm{ml}$ Trafos K, $\mathrm{T}_{12}: 2 \mathrm{ml}$ Trafos K, $\mathrm{T}_{13}$ : Tap water

\section{Number of filled grains/panicle}

Within irrigation intervals, data in Table 8 clarified that irrigation every 3 days produced the greatest number of filled grains/panicle followed by irrigation every 6 days while irrigation every 12 days gave the least because of the injury of water stress under this treatment. The results showed that the number of filled grains per panicle decreased under lower soil moisture level but the degree of reduction in different genotypes did not indicate the tolerance level of the genotypes. Decreased filled grains per panicle under lower soil moisture levels might be due to inhibition of translocation of assimilate to the grains due to moisture stress. These results agree with RRDI (1999), Niakan and Ahmadi (2014), Sokoto and Muhammad (2014), Shao et al. (2015) and Zheng et al. (2020).

Data presented in Table 8 assert that significant differences were found among the tested PGRs and biostimulants on number of filled grains/panicle in both seasons of the study. Within various PGR and biostimulant applications, plants sprayed with $1.5 \mathrm{ml} / 1$ liter Crop plus gave the highest value of number of filled grains/panicle followed by spraying also with $1 \mathrm{ml} / 1$ liter of Crop plus while spraying with $25 \mathrm{ppm}$ Cytokinin came in next rank without significance when plants sprayed with $0.5 \mathrm{ml} / 1$ liter of Crop plus in the two seasons under study. The lowest number of filled grains was obtained when rice did not receive any of PGR (control). These results are in line with that reported by Gemici et al. (1998, 2002), Wiatrak (2012b), Nayar and Bott (2014) and Niakan and Ahmadi (2014).

For the interaction of number of filled grain/panicle clarified in Table 11 that application of Crop plus under irrigation every 3-days produced the highest value of number of filled grains followed by irrigation every 9 days and surpassed both Cytokinin and $\mathrm{ABA}$ which perform the same trend. It can be also, noticed that the 
application of any of PGR to the tested cultivar caused an increase in number of filled grains as compared with control. The promoting effect of PGRs under irrigation intervals on number of filled grain/panicle were reported by Akita (1989), Gemici et al. (2002), Wiatrak (2012b), Nayar and Bott (2014) and Niakan and Ahmadi (2014).

Table 11. Number of filled grain/panicle at harvest as affected by the interaction between different irrigation intervals and growth regulators in 2018 and 2019 seasons

\begin{tabular}{l|c|c|c|c|c|c|c|c}
\hline & \multicolumn{5}{|c|}{ 2018 season } & \multicolumn{4}{c}{ 2019 season } \\
\cline { 2 - 8 } & I1 & I2 & I3 & I4 & I1 & I2 & I3 & I4 \\
\hline (T1) & $154.90 \mathrm{c}$ & $149.26 \mathrm{~d}$ & $148.00 \mathrm{~d}-\mathrm{f}$ & $144.80 \mathrm{f}-\mathrm{i}$ & $146.50 \mathrm{~d}$ & $144.20 \mathrm{e}$ & $143.60 \mathrm{e}$ & $141.80 \mathrm{~g}$ \\
(T2) & $157.60 \mathrm{abc}$ & $155.60 \mathrm{bc}$ & $149.50 \mathrm{~d}$ & $145.80 \mathrm{e}-\mathrm{i}$ & $147.50 \mathrm{c}$ & $147.50 \mathrm{c}$ & $146.70 \mathrm{~d}$ & $146.63 \mathrm{~d}$ \\
(T3) & $160.10 \mathrm{a}$ & $158.50 \mathrm{ab}$ & $156.20 \mathrm{bc}$ & $146.30 \mathrm{~d}-\mathrm{i}$ & $149.00 \mathrm{a}$ & $148.50 \mathrm{ab}$ & $147.90 \mathrm{bc}$ & $147.70 \mathrm{c}$ \\
(T4) & $148.00 \mathrm{~d}-\mathrm{f}$ & $145.50 \mathrm{f}-\mathrm{i}$ & $144.20 \mathrm{~h}-\mathrm{j}$ & $139.40 \mathrm{-n}$ & $144.00 \mathrm{e}$ & $143.70 \mathrm{e}$ & $141.40 \mathrm{~h}$ & $140.50 \mathrm{ij}$ \\
(T5) & $149.50 \mathrm{~d}$ & $148.87 \mathrm{de}$ & $144.90 \mathrm{f}-\mathrm{i}$ & $140.00 \mathrm{~lm}$ & $146.20 \mathrm{~d}$ & $143.70 \mathrm{e}$ & $141.50 \mathrm{gh}$ & $140.60 \mathrm{ij}$ \\
(T6) & $154.50 \mathrm{c}$ & $149.00 \mathrm{de}$ & $147.30 \mathrm{~d}-\mathrm{h}$ & $143.37 \mathrm{i}-\mathrm{k}$ & $146.20 \mathrm{~d}$ & $144.00 \mathrm{e}$ & $141.70 \mathrm{~g}$ & $141.40 \mathrm{gh}$ \\
(T7) & $144.80 \mathrm{f}-\mathrm{i}$ & $144.37 \mathrm{~g}-\mathrm{j}$ & $141.40 \mathrm{j}-1$ & $136.20 \mathrm{no}$ & $141.40 \mathrm{gh}$ & 137.101 & 137.001 & $133.60 \mathrm{n}$ \\
(T8) & $147.30 \mathrm{~d}-\mathrm{h}$ & $145.00 \mathrm{f}-\mathrm{i}$ & $144.00 \mathrm{~h}-\mathrm{j}$ & $136.70 \mathrm{no}$ & $141.50 \mathrm{gh}$ & $140.80 \mathrm{hi}$ & $140.00 \mathrm{j}$ & $138.10 \mathrm{k}$ \\
(T9) & $147.80 \mathrm{~d}-\mathrm{g}$ & $145.00 \mathrm{f}-\mathrm{i}$ & $144.00 \mathrm{~h}-\mathrm{j}$ & $138.971-\mathrm{n}$ & $143.70 \mathrm{e}$ & $142.90 \mathrm{f}$ & $140.30 \mathrm{ij}$ & $138.30 \mathrm{k}$ \\
(T10) & $141.40 \mathrm{jkl}$ & $135.10 \mathrm{o}-\mathrm{q}$ & $134.66 \mathrm{o}-\mathrm{q}$ & $132.40 \mathrm{qr}$ & $133.10 \mathrm{no}$ & $132.30 \mathrm{p}$ & $131.10 \mathrm{q}$ & $127.30 \mathrm{t}$ \\
(T11) & $144.00 \mathrm{~h}-\mathrm{j}$ & $140.40 \mathrm{kl}$ & $137.00 \mathrm{~m}-\mathrm{o}$ & $135.10 \mathrm{o}-\mathrm{q}$ & $136.20 \mathrm{~m}$ & $133.20 \mathrm{no}$ & $131.50 \mathrm{q}$ & $129.60 \mathrm{~s}$ \\
(T12) & $144.30 \mathrm{~h}-\mathrm{j}$ & $140.70 \mathrm{kl}$ & $140.00 \mathrm{~lm}$ & $135.70 \mathrm{op}$ & $140.40 \mathrm{ij}$ & $135.80 \mathrm{~m}$ & $132.50 \mathrm{op}$ & $129.80 \mathrm{rs}$ \\
(T13) & $140.70 \mathrm{kl}$ & $136.50 \mathrm{no}$ & $132.60 \mathrm{p}-\mathrm{r}$ & $130.80 \mathrm{r}$ & $130.40 \mathrm{r}$ & $130.40 \mathrm{r}$ & $130.00 \mathrm{rs}$ & $124.20 \mathrm{u}$ \\
\hline
\end{tabular}

I1: irrigation every 3-days, I2: irrigation every 6-days, I3: irrigation every 9-days, I4: irrigation every 12-days, $\mathrm{T}_{1}: 0.5 \mathrm{ml}$ Crop plus, $\mathrm{T}_{2}: 1.00 \mathrm{ml}$ Crop plus, $\mathrm{T}_{3}: 1.5 \mathrm{ml}$ Crop plus, $\mathrm{T}_{4}: 15 \mathrm{ppm}$ Cytokinin, $\mathrm{T}_{5}$ : $20 \mathrm{ppm}$ Cytokinin, $\mathrm{T}_{6}: 25 \mathrm{ppm}$ Cytokinin, $\mathrm{T}_{7}: 15 \mathrm{ppm} \mathrm{ABA}, \mathrm{T}_{8}: 20 \mathrm{ppm}$ ABA, $\mathrm{T}_{9}: 25 \mathrm{ppm}$ ABA, $\mathrm{T}_{10}: 1$ $\mathrm{ml}$ Trafos $\mathrm{K}, \mathrm{T}_{11}: 1.5 \mathrm{ml}$ Trafos $\mathrm{K}, \mathrm{T}_{12}: 2 \mathrm{ml}$ Trafos $\mathrm{K}, \mathrm{T}_{13}$ : Tap water

\section{Panicle weight/g}

Data in Table 12 indicated that the highest weight of panicle was obtained when rice was irrigated every 3 days followed by irrigation every 6 days, while the lowest value was obtained with irrigation every 12 days in both seasons of the study. Similar results were reported by Islam et al. (1994b), Wu et al. (2011), Abouel-Yazied et al. (2012), Li et al. (2015) and Zheng et al. (2020).

Data in the same table revealed that Plant growth regulators caused an increase in panicle weight as compared with control. The highest panicle weight (g) was found when rice plants were sprayed with Crop plus at $1.5 \mathrm{ml} / 1$ liter followed by spraying at a concentration of $1 \mathrm{ml} / 1$ liter while spraying by Crop plus by $0.5 \mathrm{ml} / 1$ liter water and Cytokinin with 25 and 20 ppm recorded nearly the same value followed by ABA which came in the third rank gave nearly the same value under different concentration of ABA in this aspect. Similar results were observed in the two seasons of the study.

Regarding the interaction effect among irrigation treatments and plant growth regulators (PGR) and biostimulants, data demonstrated that using any plant growth regulator recorded positive results under this study. Data in Table 13 show that foliar application of Crop plus by 1.5 or $1 \mathrm{ml} / 1$ liter under either the irrigation every 3-days or 6-days recorded nearly the highest values of panicle weight in the two studied seasons. It can be easily observed that there was any significant difference between the irrigation every 3-days and 6-days intervals in panicle weight when rice was treated by 1.5 or $1.00 \mathrm{ml} / 1$ liter of Crop plus. It might be due to the role of these substances to help the plant for keeping the water inside the cell longer consequently extending the period of 
irrigation intervals that led to save reasonable amount of irrigation water. These results are in good agreement with those reported by Pospíšilová et al. (1993, 2000), Pospíšilová, and Rulcová (1999), Karimi et al. (2012) and Abdel-Megeed et al. (2017).

Table 12. Panicle weight/g, 1000-grain weight/g and grain yield t/ha of Sakhal08 rice cultivars as affected by different irrigation intervals and growth regulators during 2018 and 2019 season

\begin{tabular}{|c|c|c|c|c|c|c|}
\hline \multirow[b]{2}{*}{ Treatments } & \multicolumn{3}{|c|}{2018} & \multicolumn{3}{|c|}{2019} \\
\hline & $\begin{array}{c}\text { Panicle } \\
\text { weight/g }\end{array}$ & $\begin{array}{c}\text { 1000-grain } \\
\text { weight/g }\end{array}$ & $\begin{array}{c}\text { Grain yield } \\
\text { t/ha } \\
\end{array}$ & $\begin{array}{c}\text { Panicle } \\
\text { weight/g }\end{array}$ & $\begin{array}{c}\text { 1000-grain } \\
\text { weight/g }\end{array}$ & $\begin{array}{c}\text { Grain yield } \\
\text { t/ha }\end{array}$ \\
\hline Irrigation interval (A): & & & & & & \\
\hline$\left(\mathrm{I}_{1}\right)$ & $5.51 \mathrm{a}$ & $28.54 \mathrm{a}$ & $10.79 \mathrm{a}$ & $4.87 \mathrm{a}$ & $27.32 \mathrm{a}$ & $10.94 \mathrm{a}$ \\
\hline$\left(\mathrm{I}_{2}\right)$ & $5.08 \mathrm{~b}$ & $27.63 \mathrm{ab}$ & $10.46 \mathrm{a}$ & $4.64 b$ & $26.92 b$ & $10.62 \mathrm{a}$ \\
\hline$\left(\mathrm{I}_{3}\right)$ & $4.43 c$ & $27.10 \mathrm{~b}$ & $10.02 b$ & $4.5 \mathrm{bc}$ & $26.62 b$ & $10.17 b$ \\
\hline$\left(\mathrm{I}_{4}\right)$ & $3.55 \mathrm{~d}$ & $25.60 \mathrm{c}$ & $9.59 \mathrm{~b}$ & $4.44 \mathrm{c}$ & $25.91 \mathrm{c}$ & $9.75 b$ \\
\hline F. Test & $* *$ & $* *$ & $* *$ & $* *$ & $* *$ & $* *$ \\
\hline$\frac{\text { Growth regulates }}{\text { treatment }(\mathrm{B})}$ & & & & & & \\
\hline$\left(\mathrm{T}_{1}\right)$ & $5.34 \mathrm{bc}$ & $28.65 \mathrm{abc}$ & $11.00 \mathrm{ab}$ & $5.05 \mathrm{bc}$ & $27.80 \mathrm{c}$ & $11.16 \mathrm{ab}$ \\
\hline$\left(\mathrm{T}_{2}\right)$ & $5.51 \mathrm{ab}$ & $29.23 \mathrm{ab}$ & $11.13 \mathrm{ab}$ & $5.16 \mathrm{~b}$ & $28.18 b$ & $11.28 \mathrm{ab}$ \\
\hline$\left(\mathrm{T}_{3}\right)$ & $5.71 \mathrm{a}$ & $29.70 \mathrm{a}$ & $11.38 \mathrm{a}$ & $5.49 \mathrm{a}$ & $28.79 \mathrm{a}$ & $11.53 \mathrm{a}$ \\
\hline$\left(\mathrm{T}_{4}\right)$ & $4.82 \mathrm{ef}$ & $27.17 \mathrm{~b}-\mathrm{e}$ & $10.76 b c$ & $4.67 \mathrm{~d}-\mathrm{f}$ & $27.00 \mathrm{e}$ & $10.91 b c$ \\
\hline$\left(\mathrm{T}_{5}\right)$ & $4.98 \mathrm{de}$ & $27.45 b-e$ & $10.82 \mathrm{bc}$ & $4.85 \mathrm{cde}$ & $27.38 \mathrm{~d}$ & $10.97 b c$ \\
\hline$\left(\mathrm{T}_{6}\right)$ & $5.17 \mathrm{~cd}$ & $28.18 \mathrm{a}-\mathrm{d}$ & $10.99 \mathrm{abc}$ & $4.90 \mathrm{~cd}$ & $27.63 \mathrm{~cd}$ & $11.14 \mathrm{a}-\mathrm{c}$ \\
\hline$\left(\mathrm{T}_{7}\right)$ & $4.44 \mathrm{~h}$ & $26.58 \mathrm{cde}$ & $10.08 \mathrm{~d}$ & 4.46fgh & $26.00 \mathrm{~g}$ & $10.19 \mathrm{~d}$ \\
\hline$\left(\mathrm{T}_{8}\right)$ & $4.55 \mathrm{gh}$ & $26.88 \mathrm{cde}$ & $10.53 c$ & $4.50 \mathrm{fg}$ & $26.25 \mathrm{fg}$ & $10.68 \mathrm{c}$ \\
\hline$\left(\mathrm{T}_{9}\right)$ & $4.69 \mathrm{fg}$ & $27.10 \mathrm{~b}-\mathrm{e}$ & $10.74 b c$ & $4.61 \mathrm{efg}$ & $26.50 \mathrm{f}$ & $10.89 \mathrm{bc}$ \\
\hline$\left(\mathrm{T}_{10}\right)$ & $3.68 \mathrm{jk}$ & $25.78 \mathrm{e}$ & $8.80 \mathrm{ef}$ & $3.95 \mathrm{i}$ & $25.28 \mathrm{ij}$ & $8.96 \mathrm{ef}$ \\
\hline$\left(\mathrm{T}_{11}\right)$ & $3.89 \mathrm{ij}$ & $25.90 \mathrm{de}$ & $8.94 \mathrm{ef}$ & $4.25 \mathrm{~h}$ & $25.53 \mathrm{hi}$ & $9.09 \mathrm{ef}$ \\
\hline$\left(\mathrm{T}_{12}\right)$ & $4.11 \mathrm{i}$ & 26.00de & $9.13 \mathrm{e}$ & $4.39 \mathrm{gh}$ & $25.68 \mathrm{~h}$ & $9.28 \mathrm{e}$ \\
\hline$\left(\mathrm{T}_{13}\right)$ & $3.49 \mathrm{k}$ & $25.25 \mathrm{e}$ & $8.55 \mathrm{f}$ & $3.66 \mathrm{j}$ & $25.00 \mathrm{j}$ & $8.69 \mathrm{f}$ \\
\hline F. Test & $* *$ & $*$ & $* *$ & $* *$ & $*$ & $* *$ \\
\hline Interaction: $\mathrm{AXB}$ & $* *$ & $\mathrm{~ns}$ & $*$ & $* *$ & ns & $*$ \\
\hline
\end{tabular}

I1: irrigation every 3-days, I2: irrigation every 6-days, I3: irrigation every 9-days, I4: irrigation every 12-days, $\mathrm{T}_{1}: 0.5 \mathrm{ml}$ Crop plus, $\mathrm{T}_{2}: 1.00 \mathrm{ml}$ Crop plus, $\mathrm{T}_{3}: 1.5 \mathrm{ml}$ Crop plus, $\mathrm{T}_{4}: 15 \mathrm{ppm}$ Cytokinin, $\mathrm{T}_{5}$ : $20 \mathrm{ppm}$ Cytokinin, $\mathrm{T}_{6}: 25 \mathrm{ppm}$ Cytokinin, $\mathrm{T}_{7}: 15 \mathrm{ppm} \mathrm{ABA}, \mathrm{T}_{8}: 20 \mathrm{ppm} \mathrm{ABA,} \mathrm{T}_{9}: 25 \mathrm{ppm} \mathrm{ABA}, \mathrm{T}_{10}: 1$ $\mathrm{ml}$ Trafos K, $\mathrm{T}_{11}: 1.5 \mathrm{ml}$ Trafos K, $\mathrm{T}_{12}: 2 \mathrm{ml}$ Trafos K, $\mathrm{T}_{13}$ : Tap water

\section{0-grain weight (g)}

The influence of different water intervals on the 1000-grain weight was significant in both season of the study. Data in Table 12 showed that the highest 1000-grain weight was obtained when rice plant was irrigated every 3-days without any significance under irrigation every 6-days which gave nearly the same value when rice plant was irrigated every 9-day. While the lowest weight was recorded in case of irrigation every 12-days. It could be attributed to the suitable geometric structure of rice plant which allow optimal penetration of light resulting in reasonable photosynthesis during both growth and filling periods consequently increase in metabolites stream translocated from source to sink resulting increase in filling percentage when rice plant irrigation every even 3, 6 and 9days. The results showed that 1000 grain weight was reduced with reduced soil moisture levels. Lower soil moisture might decrease translocation of assimilates to the grain which lowered grain size. Islam et al. (1994a, b), Abd Allah et al. (2009), Wu et al. (2011), Li et 
al. (2015), Abdel-Megeed et al. (2017) and Zheng et al. (2020) also stated that water stress reduced grain weight.

Table 13. Panicle weight/g as affected by the interaction between different irrigation intervals and growth regulators in 2018 and 2019 seasons

\begin{tabular}{l|c|c|c|c|c|c|c|c}
\hline & \multicolumn{5}{|c|}{2018 season } & \multicolumn{4}{c}{ 2019 season } \\
\cline { 2 - 8 } & I1 & I2 & I3 & I4 & I1 & I2 & I3 & I4 \\
\hline (T1) & $6.160 \mathrm{bc}$ & $5.940 \mathrm{cde}$ & $5.510 \mathrm{~d}-\mathrm{i}$ & $3.760 \mathrm{p}-\mathrm{t}$ & $5.430 \mathrm{bc}$ & $5.060 \mathrm{~b}-\mathrm{h}$ & $4.920 \mathrm{c}-\mathrm{j}$ & $4.780 \mathrm{~d}-\mathrm{m}$ \\
(T2) & $6.510 \mathrm{ab}$ & $6.040 \mathrm{bcd}$ & $5.660 \mathrm{c}-\mathrm{i}$ & $3.810 \mathrm{o}-\mathrm{s}$ & $5.570 \mathrm{ab}$ & $5.080 \mathrm{~b}-\mathrm{g}$ & $5.000 \mathrm{c}-\mathrm{i}$ & $4.990 \mathrm{c}-\mathrm{i}$ \\
(T3) & $6.750 \mathrm{a}$ & $6.520 \mathrm{ab}$ & $5.720 \mathrm{c}-\mathrm{i}$ & $3.840 \mathrm{o}-\mathrm{r}$ & $5.970 \mathrm{a}$ & $5.560 \mathrm{ab}$ & $5.310 \mathrm{~b}-\mathrm{d}$ & $5.100 \mathrm{~b}-\mathrm{g}$ \\
(T4) & $5.750 \mathrm{c}-\mathrm{h}$ & $5.490 \mathrm{e}-\mathrm{i}$ & $4.400 \mathrm{l}-\mathrm{n}$ & $3.620 \mathrm{p}-\mathrm{t}$ & $4.700 \mathrm{e}-\mathrm{n}$ & $4.680 \mathrm{e}-\mathrm{n}$ & $4.670 \mathrm{e}-\mathrm{n}$ & $4.630 \mathrm{f}-\mathrm{n}$ \\
(T5) & $5.780 \mathrm{c}-\mathrm{g}$ & $5.650 \mathrm{c}-\mathrm{i}$ & $4.790 \mathrm{k}-\mathrm{m}$ & $3.710 \mathrm{p}-\mathrm{t}$ & $5.150 \mathrm{~b}-\mathrm{f}$ & $4.830 \mathrm{~d}-\mathrm{l}$ & $4.710 \mathrm{e}-\mathrm{n}$ & $4.680 \mathrm{e}-\mathrm{n}$ \\
(T6) & $5.870 \mathrm{c}-\mathrm{f}$ & $5.850 \mathrm{c}-\mathrm{f}$ & $5.210 \mathrm{i}-\mathrm{k}$ & $3.760 \mathrm{p}-\mathrm{t}$ & $5.210 \mathrm{~b}-\mathrm{e}$ & $4.900 \mathrm{c}-\mathrm{k}$ & $4.770 \mathrm{~d}-\mathrm{m}$ & $4.730 \mathrm{e}-\mathrm{n}$ \\
(T7) & $5.220 \mathrm{~h}-\mathrm{k}$ & $4.900 \mathrm{kl}$ & $4.120 \mathrm{n}-\mathrm{q}$ & $3.500 \mathrm{r}-\mathrm{v}$ & $4.570 \mathrm{~g}-\mathrm{o}$ & $4.510 \mathrm{~h}-\mathrm{p}$ & $4.400 \mathrm{j}-\mathrm{q}$ & $4.350 \mathrm{k}-\mathrm{q}$ \\
(T8) & $5.290 \mathrm{~g}-\mathrm{k}$ & $5.200 \mathrm{ijk}$ & $4.150 \mathrm{n}-\mathrm{p}$ & $3.540 \mathrm{r}-\mathrm{u}$ & $4.640 \mathrm{f}-\mathrm{n}$ & $4.520 \mathrm{~h}-\mathrm{p}$ & $4.440 \mathrm{i}-\mathrm{p}$ & $4.410 \mathrm{j}-\mathrm{q}$ \\
(T9) & $5.540 \mathrm{~d}-\mathrm{i}$ & $5.360 \mathrm{fj}$ & $4.280 \mathrm{mnno}$ & $3.570 \mathrm{r}-\mathrm{u}$ & $4.680 \mathrm{e}-\mathrm{n}$ & $4.600 \mathrm{f}-\mathrm{o}$ & $4.600 \mathrm{f}-\mathrm{o}$ & $4.550 \mathrm{~g}-\mathrm{p}$ \\
(T10) & $4.5801-\mathrm{n}$ & $3.610 \mathrm{q}-\mathrm{u}$ & $3.280 \mathrm{~s}-\mathrm{v}$ & $3.240 \mathrm{tuv}$ & $4.250 \mathrm{~m}-\mathrm{s}$ & $3.880 \mathrm{q}-\mathrm{t}$ & $3.880 \mathrm{q}-\mathrm{t}$ & $3.770 \mathrm{r}-\mathrm{u}$ \\
(T11) & $4.770 \mathrm{k}-\mathrm{m}$ & $3.810 \mathrm{o}-\mathrm{i}$ & $3.660 \mathrm{p}-\mathrm{t}$ & $3.350 \mathrm{r}-\mathrm{v}$ & $4.470 \mathrm{i}-\mathrm{p}$ & $4.460 \mathrm{i}-\mathrm{p}$ & $4.070 \mathrm{o}-\mathrm{s}$ & $4.010 \mathrm{p}-\mathrm{s}$ \\
(T12) & $4.890 \mathrm{jk1}$ & $4.290 \mathrm{mnn}$ & $3.750 \mathrm{p}-\mathrm{t}$ & $3.490 \mathrm{r}-\mathrm{v}$ & $4.490 \mathrm{i}-\mathrm{p}$ & $4.480 \mathrm{i}-\mathrm{p}$ & $4.3001-\mathrm{q}$ & $4.2801-\mathrm{r}$ \\
(T13) & $4.500 \mathrm{lmn}$ & $3.410 \mathrm{r}-\mathrm{v}$ & $3.080 \mathrm{uv}$ & $3.000 \mathrm{v}$ & $4.170 \mathrm{n}-\mathrm{s}$ & $3.750 \mathrm{stu}$ & $3.410 \mathrm{tu}$ & $3.320 \mathrm{u}$ \\
\hline
\end{tabular}

I1: irrigation every 3-days, I2: irrigation every 6-days, I3: irrigation every 9-days, I4: irrigation every 12-days, $\mathrm{T}_{1}: 0.5 \mathrm{ml}$ Crop plus, $\mathrm{T}_{2}: 1.00 \mathrm{ml}$ Crop plus, $\mathrm{T}_{3}: 1.5 \mathrm{ml}$ Crop plus, $\mathrm{T}_{4}: 15 \mathrm{ppm}$ Cytokinin, $\mathrm{T}_{5}$ : $20 \mathrm{ppm}$ Cytokinin, $\mathrm{T}_{6}: 25 \mathrm{ppm}$ Cytokinin, $\mathrm{T}_{7}: 15 \mathrm{ppm} \mathrm{ABA}, \mathrm{T}_{8}: 20 \mathrm{ppm} \mathrm{ABA,} \mathrm{T}_{9}: 25 \mathrm{ppm}$ ABA, $\mathrm{T}_{10}: 1$ $\mathrm{ml}$ Trafos K, $\mathrm{T}_{11}: 1.5 \mathrm{ml}$ Trafos K, $\mathrm{T}_{12}: 2 \mathrm{ml}$ Trafos K, $\mathrm{T}_{13}$ : Tap water

From the result presented in Table 12 spraying Crop plus with different concentrations and $25 \mathrm{ppm}$ concentration of Cytokinin recorded nearly equal value of the highest 1000-grain weight/g followed by spraying with concentration of 20 and 15 ppm of Cytokinin while spraying of ABA and Trafos K came in the last rank. Whereas, control gave the lowest value of 1000-grain weight in both seasons. It can be easily noticed that the application of the plant growth regulating substance caused an increase in 1000-grain weight/g as compared with control treatments (Tap water). The treatments which did not involve plant growth regulator produced the lowest values in this aspect.

\section{Grain yield t/ha}

Data indicated that there was significant effect on rice grain yield due to the effect of different water intervals in both seasons of study as shown in Table 12. Irrigation every 3 and 6-days gave the highest grain yield in the two seasons of study followed by and 9-days which came in the second rank while irrigation every 12-days recorded the lowest grain yield in both seasons of the study. This mean irrigation every 6-days gave yield almost equal to irrigation every 3-days with saving more water for irrigation every 6-days. On the other side the reduction in grain yield under irrigation every 12 days could be attributed to the water stress which cause a decrease in both number of tillers and panicles, LAI, chlorophyll content, water and nutrient uptake as well as the shrinking in cell protoplasm, cell division and elongation consequently cause a reduction in the morphological and physiological process in the plant such as photosynthesis and its assimilates resulted in a decrease in filling percentage and rates which produced low panicle and 1000-grain weight that cause a significant reduction in the grain yield. There was a linear relationship between available water and yield, where reduction in available water limits evapotranspiration and 
consequently reduced yield, as reported by several researchers Hossain (2001), El- Refaee et al. (2012) and El-Habet (2014) reported that water stress at filling grains period with acceleration in ripening time, casing to a decreasing growth duration period which led to a reduction in grain filling. So, it was observed that grain yield per hill decreased in decreasing soil moisture level. Reduced grain yield under lower soil moisture levels might be due to inhibition of photosynthesis and less translocation of assimilates towards grain due to soil moisture stress. The results also agree with Akita (1989), Abouel-Yazied et al. (2012), Pospíśilová et al. (2000) and Hossain (2001).

Data listed in Table 12 substantiated that, highly significant differences were found among different plant growth regulators (PGRs) and biostimulated grain yield in both seasons of study. Data indicated that Crop plus treatments of plant growth biostimulated at all tested growth stages with different concentrations and Cytokinin when rice plant was treated by $25 \mathrm{ppm}$ concentration surpassed the other plant growth regulator recorded nearly the same value of grain yield and came in the first rank followed by when rice plant was treated by 15 and 20 ppm of Cytokinin came in the second rank in the two seasons of the study without any significant differences among them. The lowest value of grain yield was recorded when rice plant was not treated by any of plant growth regulator (Tap water only).

Data listed in Table 14 revealed that statistical differences were found in grain yield due to the interaction between different irrigation intervals and various plant growth regulators in both seasons. Spraying Crop plus with different concentration even 1.5, 1.00 and 0.5 $\mathrm{ml} / 1$ liter water gave the highest grain yield under irrigation every 3, 6 and 9-days without any significant difference between them. For Cytokinin data showed also spraying with 25 ppm recorded the highest grain yield under irrigation 3 and 6-days and come in the second rank after Crop plus. Data revealed also Crop plus recorded superiority and recorded the highest grain yield under irrigation every 12-days than another plant growth regulator which recorded positive result under irrigation every 12 day and came in the second rank after Crop plus.

Table 14. Grain yield t/ha as affected by the interaction between different irrigation intervals and growth regulators in 2018 and 2019 seasons

\begin{tabular}{l|c|c|c|c|c|c|c|c}
\hline & \multicolumn{5}{|c|}{$\mathbf{2 0 1 8}$ season } & \multicolumn{4}{c}{ 2019 season } \\
\cline { 2 - 9 } & I1 & $\mathbf{I 2}$ & $\mathbf{I 3}$ & $\mathbf{I 4}$ & $\mathbf{I 1}$ & $\mathbf{I 2}$ & I3 & I4 \\
\hline (T1) & $11.540 \mathrm{a}-\mathrm{c}$ & $11.180 \mathrm{a}-\mathrm{e}$ & $10.860 \mathrm{~b}-\mathrm{f}$ & $10.430 \mathrm{~d}-\mathrm{h}$ & $11.693 \mathrm{a}-\mathrm{c}$ & $11.333 \mathrm{a}-\mathrm{e}$ & $11.013 \mathrm{~d}-\mathrm{f}$ & $10.583 \mathrm{~d}-\mathrm{h}$ \\
(T2) & $11.710 \mathrm{ab}$ & $11.270 \mathrm{a}-\mathrm{d}$ & $11.090 \mathrm{a}-\mathrm{e}$ & $10.440 \mathrm{~d}-\mathrm{h}$ & $11.863 \mathrm{ab}$ & $11.423 \mathrm{a}-\mathrm{d}$ & $11.243 \mathrm{a}-\mathrm{e}$ & $10.593 \mathrm{~d}-\mathrm{h}$ \\
(T3) & $12.080 \mathrm{a}$ & $11.490 \mathrm{abc}$ & $11.200 \mathrm{a}-\mathrm{e}$ & $10.730 \mathrm{~b}-\mathrm{f}$ & $12.233 \mathrm{a}$ & $11.643 \mathrm{a}-\mathrm{c}$ & $11.353 \mathrm{a}-\mathrm{e}$ & $10.883 \mathrm{~b}-\mathrm{f}$ \\
(T4) & $11.150 \mathrm{a}-\mathrm{e}$ & $10.840 \mathrm{~b}-\mathrm{f}$ & $10.700 \mathrm{~b}-\mathrm{f}$ & $10.340 \mathrm{~d}-\mathrm{j}$ & $11.303 \mathrm{a}-\mathrm{e}$ & $10.993 \mathrm{~d}-\mathrm{f}$ & $10.853 \mathrm{~b}-\mathrm{f}$ & $10.493 \mathrm{~d}-\mathrm{j}$ \\
(T5) & $11.180 \mathrm{a}-\mathrm{e}$ & $11.010 \mathrm{~b}-\mathrm{e}$ & $10.720 \mathrm{~d}-\mathrm{j}$ & $10.370 \mathrm{~d}-\mathrm{j}$ & $11.333 \mathrm{a}-\mathrm{e}$ & $11.163 \mathrm{~b}-\mathrm{e}$ & $10.873 \mathrm{~b}-\mathrm{f}$ & $10.523 \mathrm{~d}-\mathrm{j}$ \\
(T6) & $11.540 \mathrm{abc}$ & $11.160 \mathrm{a}-\mathrm{e}$ & $10.850 \mathrm{~d}-\mathrm{j}$ & $10.410 \mathrm{~d}-\mathrm{i}$ & $11.693 \mathrm{a}-\mathrm{c}$ & $11.313 \mathrm{a}-\mathrm{e}$ & $11.003 \mathrm{~b}-\mathrm{f}$ & $10.563 \mathrm{~d}-\mathrm{i}$ \\
(T7) & $10.850 \mathrm{~b}-\mathrm{f}$ & $10.600 \mathrm{c}-\mathrm{g}$ & $10.200 \mathrm{~d}-\mathrm{i}$ & $8.500 \mathrm{mo}$ & $11.003 \mathrm{~b}-\mathrm{f}$ & $10.753 \mathrm{c}-\mathrm{g}$ & $10.353 \mathrm{e}-\mathrm{j}$ & $8.653 \mathrm{~m}-\mathrm{o}$ \\
(T8) & $11.130 \mathrm{a}-\mathrm{e}$ & $10.510 \mathrm{c}-\mathrm{h}$ & $10.230 \mathrm{~m}-\mathrm{o}$ & $10.230 \mathrm{~d}-\mathrm{j}$ & $11.283 \mathrm{a}-\mathrm{e}$ & $10.663 \mathrm{c}-\mathrm{h}$ & $10.383 \mathrm{~d}-\mathrm{j}$ & $10.383 \mathrm{~d}-\mathrm{j}$ \\
(T9) & $11.130 \mathrm{a}-\mathrm{e}$ & $10.800 \mathrm{~b}-\mathrm{f}$ & $10.690 \mathrm{~d}-\mathrm{j}$ & $10.340 \mathrm{~d}-\mathrm{j}$ & $11.283 \mathrm{a}-\mathrm{e}$ & $10.953 \mathrm{~b}-\mathrm{f}$ & $10.843 \mathrm{~b}-\mathrm{f}$ & $10.493 \mathrm{~d}-\mathrm{j}$ \\
(T10) & $9.400 \mathrm{j}-\mathrm{m}$ & $9.170 \mathrm{k}-\mathrm{n}$ & $8.350 \mathrm{no}$ & $8.290 \mathrm{no}$ & $9.553 \mathrm{j}-\mathrm{m}$ & $9.323 \mathrm{k}-\mathrm{n}$ & $8.503 \mathrm{no}$ & $8.443 \mathrm{no}$ \\
(T11) & $9.630 \mathrm{~g}-\mathrm{l}$ & $9.410 \mathrm{i}-\mathrm{m}$ & $8.380 \mathrm{no}$ & $8.330 \mathrm{no}$ & $9.783 \mathrm{~g}-\mathrm{l}$ & $9.563 \mathrm{i}-\mathrm{m}$ & $8.533 \mathrm{no}$ & $8.483 \mathrm{no}$ \\
(T12) & $9.890 \mathrm{f}-\mathrm{k}$ & $9.560 \mathrm{~h}-\mathrm{l}$ & $8.730 \mathrm{no}$ & $8.330 \mathrm{no}$ & $10.043 \mathrm{f}-\mathrm{k}$ & $9.713 \mathrm{~h}-\mathrm{l}$ & $8.8831-\mathrm{o}$ & $8.483 \mathrm{no}$ \\
(T13) & $9.010 \mathrm{k}-\mathrm{n}$ & $9.000 \mathrm{k}-\mathrm{n}$ & $8.190 \mathrm{no}$ & $7.980 \mathrm{o}$ & $9.163 \mathrm{k}-\mathrm{n}$ & $9.153 \mathrm{k}-\mathrm{n}$ & $8.343 \mathrm{no}$ & $8.133 \mathrm{o}$ \\
\hline
\end{tabular}

I1: irrigation every 3-days, I2: irrigation every 6-days, I3: irrigation every 9-days, I4: irrigation every 12-days, $\mathrm{T}_{1}: 0.5 \mathrm{ml}$ Crop plus, $\mathrm{T}_{2}: 1.00 \mathrm{ml}$ Crop plus, $\mathrm{T}_{3}: 1.5 \mathrm{ml}$ Crop plus, $\mathrm{T}_{4}: 15 \mathrm{ppm}$ Cytokinin, $\mathrm{T}_{5}$ : 20 ppm Cytokinin, $\mathrm{T}_{6}: 25$ ppm Cytokinin, $\mathrm{T}_{7}: 15$ ppm ABA, $\mathrm{T}_{8}: 20$ ppm ABA, T9: 25 ppm ABA, $\mathrm{T}_{10}: 1$ ml Trafos K, $\mathrm{T}_{11}: 1.5 \mathrm{ml}$ Trafos $\mathrm{K}, \mathrm{T}_{12}: 2 \mathrm{ml}$ Trafos $\mathrm{K}, \mathrm{T}_{13}$ : Tap water 
The high concentration of any plant growth regulator under this study recorded the highest grain yield under irrigation every 3, 6, 9 and 12-days as compared with control (Tap water). While the lowest grain yield was recorded under irrigation every 12 days when rice plant was not treated with any plant growth regulator. From the previous studies, spraying with biozyme Crop plus, a commercial formulation of seaweed extract (Ascophyllum nodosum), enzymes and hydrolyzed proteins whereas, Spic cytozyme contain gibberellic acid, auxins, Cytokinins, seaweed extract (Ascophyllum nodosum), hydrolyzed proteins and trace elements. Also, spraying of Cytokinin $(\mathrm{CK})$ on the grains during the growth stage leads to increase in Cytokinin (CK) in these organs. Increased Cytokinin (CK) concentration in seeds during cell division caused increase in the number of endospermic cells which had positive correlation with the increase in grain yield (Morris et al., 1993). The same trend was observed with high concentration of ABA $(25 \mathrm{ppm})$ in the two studied seasons. It can be observed that under irrigation every 3 and 6-days there were not any significant differences among the tested PGRs Crop plus and Cytokinin. It is important to observe that Crop plus relieves the harm of water stress under irrigation every 12 days followed by Cytokinin and ABA as compared with control in the two studied seasons. Crop plus is synthetised in rice roots and directly increase the root depth and volume and its viability as a result to free amino acid metabolism. The Crop plus translocated to the rice shoots and indirectly controlled protein metabolism and chlorophyll biosynthesis as well as increased cell division and elongation, also, the Crop plus inhibited the senescence of leaves and increased the viability of leaves especially flag leaf and both the second and third leaves which caused an increase in photosynthesis and its product (assimilates) resulted in increased filling \% that produced the heavier grains. Also, Cytokinin concentration was high in the spikelets during filling period and caused an increase in cell division and elongation in the spikelets and then reached to the minimum concentration at the end of the filling period. According to the findings of Kermode et al. (1989) and Yang et al. (2003) they found that the increase in $\mathrm{ABA}$ concentration at the beginning of cell division decreased it significantly. Also, ABA, contrary to $\mathrm{CK}$, can reduce the grain filling period via stimulation of aging (Nooden, 1988) resulting in grain yield loss. The results also agree with Ashikari et al. (2005), Wiatrak (2012a, b), Nayar and Bott (2014) and Niakan and Ahmadi (2014).

\section{Conclusion}

Irrigation every 3 days gave the highest grain yield without any significant differences with irrigation every 6 days followed by 9 days while irrigation every 12 days recorded the lowest grain yield. According to the previous results, it can be concluded that sprayed Sakha 108 rice cultivar by Crop plus and cytokinin under water stress increase the rice grain yield. Also, Sakha 108 rice cultivar responded to Crop plus application compared to other regulator growth under water stress. Spraying with crop plus $1.5 \mathrm{ml} / \mathrm{l}$ prolonged the irrigation interval from 3 days up to 9 days without any significant difference in grain yield.

These results are very important for the farmers whose have shortage of water in rice fields. Finally, this study is needed to be extended to reach the best results about utilization of different growth regulators under different levels of water stress. Further studies are required to determine the amount of water irrigation under Egyptian condition. 


\section{REFERENCES}

[1] Abd Allah, A. A., Mohamed, A. A. A., Gab-Allah, M. M. (2009): Genetic studies of some physiological and shoot characters in relation to drought tolerance in rice. $-\mathrm{J}$. Agric. Res. Kafrelsheikh Univ. 35(4).

[2] Abdel-Megeed, T. M., El-Habet, H., Hashem, I. M., Badawy, S. A. (2017): Impact of some Plant Growth Regulating substances on the yield and its components of Giza179 and Giza177 rice cultivars under different irrigation interval treatments. - J. Plant Production, Mansoura Univ., Vol. 8(3): 369-379.

[3] Abouel-Yazied, A., El-Gizawy, A. M., Ragab, M. I., Hamed, E. S. (2012): Effect of seaweed extract and compost treatments on growth, yield and quality of snap bean. Journal of American Science 8(6).

[4] Abubakar, A. R., Ashraf, N., Ashraf, M. (2012): Effect of plant biostimulants on flowering, fruit drop, yield and return bloom of pomegranate CV. Kandhari Kabuli. Asian J. Hort. 7(2): 473-477.

[5] Akita, S. (1989): Field Evaluation of Cytozyme Crop Plus on Grain Yield of Rice (Preliminary Results), Worldwide Research on Cytozyme Products. Abstract. Cytozyme Laboratories Inc., South Salt Lake, UT.

[6] Anonymous (2013): Bio-stimulants market - by active ingredients, application, crop types \& geography-global trends \& forecasts to 2018. - Markets and Markets. https://www.marketsandmarkets.com/Market-Reports/biostimulant-market-1081.html.

[7] Ashikari, M., Sakakibara, H., Lin, S., Yamamoto, T., Takashi, T., Nishimura, A., Angeles, E. R., Qian, Q., Kitano, H., Matsuoka, M. (2005): Cytokinin oxidase regulates rice grain production. - Science 309(29).

[8] Bahattacharjee, D. P., Krishnayya, G. R., Ghosh, A. K. (1973): Analyses of yield components and productive efficiency of rice varieties under soil moisture deficit. Indian Journal of Agronomy 16: 314-343.

[9] Bhattacharya, A. (2019): Effect of High-Temperature Stress on the Metabolism of Plant Growth Regulators. Chapter 6. - Indian Institute of Pulses Research, Kanpur, pp. 485591.

[10] Black, C.A., Evans, D. D., Ensminger, L. E., Clark, F. E. (1965): Methods of Soil Analysis. Part 2. Chemical and Microbiological Properties. - American Soc. of Agronomy, Inc., Publisher, Madison, WI.

[11] Blum, A. (1996): Crop responses to drought and the interpretation of adaptation. - Plant Growth Reg. 20(2): 135-148.

[12] Canady, M. (2012): Effect of Crop plus on Physiological Response Related to Photosynthesis in Citrus. - Technical Data Reports 10(1). Cytozyme Laboratories, Inc., South Salt Lake, UT.

[13] Cowan, A. K., Cairns, A. L. P., Bartels-Rahm, B. (1999): Regulation of abscisic acid metabolism: towards a metabolic basis for abscisic acid-cytokinin antagonism. - J. Exp. Bot. 50: 595-603.

[14] Craigie, J. S (2011): Seaweed extract stimuli plant science and agriculture. - J. Appl. Phycol. 23: 371-393.

[15] De Datta, S. K., Abilay, W. P., Kalwar (1973) Water Stress Effect on Flooded Tropical rice. - In: Water Management in Philippine Irrigation System: Research and Operation. Papers Presented at the Water Management Workshop, December 11-14, 1972, Cairo, Egypt, pp. 16-36.

[16] El-Habet, H. B. (2014): Irrigation regime and potassium levels effects on yield of some rice genotypes, water use efficiency (WUE) and economic returns. - Journal of Plant Production 5(3): 383-399.

[17] El-Refaee. I. S., Gorgy, R. N., Metwally, T. F. (2012): Response of some rice cultivars to plant spacing for improving grain yield and water productivity under different irrigation intervals. - Alex. J. Agric. Res. 57(1): 1-14. 
[18] European Biostimulants Industry Council (2013): Economic Overview of the Biostimulants Sector in Europe. - EBIC.

[19] Gemici, M. (1993): Effect of cytozyme crop plus on Triticum durum (wheat). - Doga-Tr. J. of Botany 17. 133-139.

[20] Gemici, M., Güven, A., Katmer, P. (1998): Effects of cytozyme crop plus on Lycopersicum esculentum mill. plant yield. - Tr. J. of Botany 22: 7-11.

[21] Gemici, M., Güven, A., Kamil, A., Reklü, Y., Katmer, P. (2002): Effect of some growth regulators and commercial preparations on the chlorophyll content and mineral nutrition of Lycopersicum esculentum Mill. - Turk J Bot. 24: 215-219.

[22] Gomes, A. K., Gomes, A. A. (1984): Statistical Procedures of Agricultural Research. 2nd Ed. - Wiley, New York.

[23] Hare, P. D., Cress, W. A., Van Staden, J. (1997): The involvement of cytokinins in plant responses to environmental stress. - Plant Growth Regul. 23: 79-103.

[24] Hossain, M. A. (2001): Growth and yield performance of some boro rice cultivars under different soil moisture regimes. - M. S. Thesis, Dep. Crop Bot. Bangladesh Agric. Univ., Mymensingh.

[25] Houssien, A. A., Ismail, A. A., Sabra, F. S. (2011): Bioactive substance extracted from seaweeds as a biocontrol agents, effects and identification. - Journal of Agriculture Research, Kafrelsheikh University 37: 460-473.

[26] Islam, M. T., Islam, M. T., Salam, M. A. (1994a): Growth and yield performance of some rice genotypes under different soil moisture regimes. - Bangladesh J. Trg. and Dev. 7(2): 57-62.

[27] Islam, M. T., Salam, M. A., Kauser, M. (1994b): Effect of soil water stress at different growth stages of rice of yield components and yield. - Progress. Agric 5(20): 151-156.

[28] Kamínek, M., Motyka, V., Vaňková, R. (1997): Regulation of cytokinin content in plant cells. - Physiol. Plant. 101: 689-700.

[29] Kang, S. (1998): New agricultural sci-technological revolution and development of Chinese water-saving agriculture in 21st century. - Agricultural Research in the Arid Areas 16(1): 11 (in Chinese).

[30] Karimi, A., Tajbakhsh, M., Nia, R. A., Eivazi, A.-R., Karimi, K. (2012): Effects of inducing plant growth on performance and performance components of Corn (Zea mays L.). - Life Sci J 9(4): 223-229.

[31] Kermode, A. R., Oishi, M. Y., Bewleym, J. D. (1989): Regulatory Roles for Desiccation and ABA in Seed Development. A Comparison of the Evidence from Whole Seeds and Isolated Embryos. - In: Stanwood, P. C., Mcdonald, M. B. (eds.) Seed Moisture. CSSA Special Publication, Madison, WI, pp. 23-50.

[32] Levitt, J. (1980): Responses of Plants to Environmental Stress. Vol. 2. - Academic Press, New York.

[33] Li, Q., Bian, C., Liu, X., Ma, C., Liu, Q. (2015): Winter wheat grain yield and water use efficiency in wide precision planting pattern under deficit irrigation in North China Plain. - Agric. Water Manag. 153: 71-76.

[34] Morris, R. D., Blevins, D. G., Dietrich, J. T., Durly, R. C., Gelvin, S. B., Gray, J., Hommes, N. G., Aminek, M., Mathews, L. J., Meilan, R., Reinbott, T. M., SagavendraSoto, L. (1993): Cytokinins in plant pathogenic bacteria and developing cereal grains. Australian Journal of Plant Physiology 20: 621-637.

[35] Nayar, S., Bott, K. (2014): Current status of global cultivated seaweed production and markets. - World Aquac 45: 32-37.

[36] Niakan, M., Ahmadi, A. (2014): Effects of foliar spraying kinetin on growth parameters and photosynthesis of tomato under different levels of drought stress. - Iranian Journal of Plant Physiology 4(2): 939-947.

[37] Nooden, L. D. (1988): Abscisic Acid, Auxin, and Other Regulators of Senesce. Academic Press, San Diego, pp. 329-368. 
[38] Pospíšilová, J., Čatský, J., Synková, H., Macháčková, I., Solárová, J. (1993): Gas exchange and in vivo chlorophyll fluorescence in potato and tobacco plantlets in vitro as affected by various concentrations of 6-benzylaminopurine. - Photosynthetica 29: 1-12.

[39] Pospíšilová, J., Rulcová, J. (1999): Can synthetic cytokinins alleviate water stress in Phaseolus vulgaris leaves? - Biol. Plant. 42(Suppl.): S77.

[40] Pospíśilová, J., Synková, H., Rulcová, J. (2000): Cytokinins and water stress. - Biologia Plantarum 43(3): 321-328.

[41] Prajapati, K., Modi, H. A. (2012): The importance of potassium in plant growth. A Review. - Indian Journal of Plant Sciences 1(02-03): 177-186.

[42] Ramya, S. S., Nagaraj, S., Vijayanand, N. (2011): Influence of seaweed liquid extracts on growth, biochemical and yield characteristics of Cyamopsis tetragonolaba (L.) Taub. Journal of Phytology 3(9): 37-41.

[43] RRDI (Rice Research and Development Institute) (1999): Netscape - Effect of Water Deficit. - Dept. Agric., Batalagoda, Ibbagamuwa, Srilanka.

[44] Shao, G., Cui, J., Yu, S. E., Lu, B., Brian, B. J., Ding, J., She, D. (2015): Impacts of controlled irrigation and drainage on the yield and physiological attributes of rice. Agric. Water Manag. 149: 156-165.

[45] Sokoto, M. B., Muhammad, A. (2014): Response of rice varieties to water stress in Sokoto, Sudan Savannah, Nigeria. - Journal of Biosciences and Medicines 2: 68-74.

[46] Sultana, V., Ehteshamul-Haque, S., Ara, J., Athar, M. (2005): Comparative efficacy of brown, green and red seaweed in the control of root infecting fungi and okra. - Int. J. Environ. Sci. Tech. 2(2): 129-132.

[47] Waller, R. A., Ducan, D. B. (1969): Bayes rule for the Symmetric Malliple Comason problem. - J. Am. Stat, Assoc. 64: 1484-1499.

[48] Wiatrak, P. (2012a): Effect of Crop plus on corn production. - Technical Data Reports 10(1). Cytozyme Laboratories, Inc., South Salt Lake, UT.

[49] Wiatrak, P. (2012b): Effect of Seed + Extra and Crop plus on yield in a soybean irrigation trial. - Technical Data Reports 10(1), SBEAUSUT1701. Cytozyme Laboratories, Inc., South Salt Lake, UT.

[50] Wu, N., Guan, Y., Shi, Y. (2011): Effect of water stress on physiological traits and yield in rice backcross lines after anthesis. - Energy Procedia 5: 255-260.

[51] Wu, X. H., Wang, W., Xie, X. L., Yin, C. M., Xie, K. J. (2018): Photosynthetic and yield responses of rice (Oryza sativa L.) to different water management strategies in subtropical China. - Photosynthetica 56: 1031-1038.

[52] Yamaguchi, T., Tuan, L. M., Minamikawa, K., Yokoyama, S. (2019): Assessment of the relationship between adoption of a knowledge-intensive water-saving technique and irrigation conditions in the Mekong Delta of Vietnam. - Agric. Water Manag. 212: 162171.

[53] Yan, T., Wang, J., Huang, J. (2015): Urbanization, agricultural water use, and regional and national crop production in China. - Ecol. Model. 318: 226-235.

[54] Yang, J., Zhang, J., Wang, Z., Liu, L., Zhu, Q. (2003): Postanthesis water deficits enhance grain filling in two line hybrid rice. - Crop Sci. 43: 2099-2108.

[55] Zhang, J., Jia, Y., Ismail, M. (2006): Role of ABA in integrating plant responses to drought and salt stresses. - Field Crops Research 97: 111-119.

[56] Zheng, C., Zhang, Z., Hao, S., Chen, W., Pan, Y., Wang, Z. (2020): agronomic growth performance of super rice under water-saving irrigation methods with different watercontrolled thresholds in different growth stages. - Agronomy 10: 239. 